\title{
Overexpression of copper/zinc superoxide dismutase from mangrove Kandelia candel in tobacco enhances salinity tolerance by the reduction of reactive oxygen species in chloroplast
}

\author{
Xiaoshu Jing ${ }^{1}$, Peichen Hou ${ }^{2}$, Yanjun Lu ${ }^{1}$, Shurong Deng ${ }^{1}, \mathrm{Niya}_{\mathrm{Li}}{ }^{3}$, Rui Zhao ${ }^{1}$, Jian Sun ${ }^{4}$, \\ Yang Wang ${ }^{1}$, Yansha Han ${ }^{1}$, Tao Lang ${ }^{1}$, Mingquan Ding ${ }^{5}$, Xin Shen ${ }^{1}$ and Shaoliang Chen ${ }^{1}$ * \\ ${ }^{1}$ Department of Plant Science, College of Biological Sciences and Technology, Beijing Forestry University, Beijing, China \\ 2 Department of Bio-Instruments, National Engineering Research Center for Information Technology in Agriculture, Beijing, China \\ ${ }^{3}$ Department of Biology, College of Life Science, Hainan Normal University, Haikou, China \\ ${ }^{4}$ Department of Plant Science, College of Life Science, Jiangsu Normal University, Xuzhou, China \\ ${ }^{5}$ Department of Crop Science, College of Agricultural and Food Science, Zhejiang Agricultural and Forestry University, Hangzhou, China
}

Edited by:

Vadim Volkov, London Metropolitan

University, UK

Reviewed by:

Dejuan Euring,

Georg-August-Universität Göttingen

Germany

Kai Chen, Environment Canada,

Canada

Isacco Beritognolo, CNR Istituto di

Biologia Agroambientale e

Forestale, Italy

*Correspondence:

Shaoliang Chen, College of

Biological Sciences and Technology,

Beijing Forestry University,

Qinghua-East Road 35, Haidian,

Beijing 100083, China

e-mail: Ischen@bjfu.edu.cn
$\mathrm{Na}^{+}$uptake and transport in Kandelia candel and antioxidative defense were investigated under rising $\mathrm{NaCl}$ stress from 100 to $300 \mathrm{mM}$. Salinized K. candel roots had a net $\mathrm{Na}^{+}$efflux with a declined flux rate during an extended $\mathrm{NaCl}$ exposure. $\mathrm{Na}^{+}$buildup in leaves enhanced $\mathrm{H}_{2} \mathrm{O}_{2}$ levels, superoxide dismutase (SOD) activity, and increased transcription of CSD gene encoding a $\mathrm{Cu} / \mathrm{Zn}$ SOD. Sequence and subcellular localization analyses have revealed that $\mathrm{KcCSD}$ is a typical $\mathrm{Cu} / \mathrm{Zn} \mathrm{SOD}$ in chloroplast. The transgenic tobacco experimental system was used as a functional genetics model to test the effect of $\mathrm{KcCSD}$ on salinity tolerance. $\mathrm{KcCSD}$-transgenic lines were more $\mathrm{Na}^{+}$tolerant than wildtype (WT) tobacco in terms of lipid peroxidation, root growth, and survival rate. In the latter, $100 \mathrm{mM} \mathrm{NaCl}$ led to a remarkable reduction in chlorophyll content and a/b ratio, decreased maximal chlorophyll a fluorescence, and photochemical efficiency of photosystem II. $\mathrm{NaCl}$ stress in WT resulted from $\mathrm{H}_{2} \mathrm{O}_{2}$ burst in chloroplast. $\mathrm{Na}^{+}$injury to chloroplast was less pronounced in KCCSD-transgenic plants due to upregulated antioxidant defense. KCCSDtransgenic tobacco enhanced SOD activity by an increment in SOD isoenzymes under $100 \mathrm{mM} \mathrm{NaCl}$ stress from $24 \mathrm{~h}$ to 7 day. Catalase activity rose in KcCSD overexpressing tobacco plants. KCCSD-transgenic plants better scavenged $\mathrm{NaCl}$-elicited reactive oxygen species (ROS) compared to WT ones. In conclusion, K. candel effectively excluded $\mathrm{Na}^{+}$in roots during a short exposure; and increased CSD expression to reduce ROS in chloroplast in a long-term and high saline environment.

Keywords: Kandelia candel, $\mathrm{Na}^{+}$flux, superoxide anion, hydrogen peroxide, salt, catalase, superoxide dismutase

\section{INTRODUCTION}

$\mathrm{NaCl}$-exposed plants accumulate a high level of $\mathrm{Na}^{+}$in roots and leaves regardless of $\mathrm{Na}^{+}$-resistant or -sensitive species (Chen and Polle, 2010; Polle and Chen, 2014). $\mathrm{Na}^{+}$excess would lead to ionic imbalance, causing $\mathrm{Na}^{+}$injury (Volkov et al., 2004). To avoid excessive buildup of $\mathrm{Na}^{+}$, non-secretor mangrove species (Kandelia candel) can maintain a high capacity to restrict $\mathrm{Na}^{+}$ uptake and transport after $\mathrm{NaCl}$ exposure (Li et al., 2008). K. candel roots exhibited $\mathrm{Na}^{+}$efflux by increasing $\mathrm{H}^{+}$influx, indicating that $\mathrm{Na}^{+}$efflux resulted from active $\mathrm{Na}^{+}$exclusion across the plasma membrane (Lu et al., 2013; Lang et al., 2014). However, its roots and shoots could accumulate large amount of $\mathrm{Na}^{+}$under a long-term of increasing salinity (Li et al., 2008). This implies that the capacity for $\mathrm{Na}^{+}$exclusion decreased in salinized roots. However, this hypothesis needs further investigations.

In addition to ion-specific toxicity, $\mathrm{Na}^{+}$accumulation in leaves leads to oxidative stress by the production of reactive oxygen species (ROS) in trees (Wang et al., 2007, 2008). Superoxide anions $\left(\mathrm{O}_{2}^{-}\right)$are generated as a byproduct of electron transport mainly in mitochondria or chloroplasts, which results in subsequent formation of hydrogen peroxide $\left(\mathrm{H}_{2} \mathrm{O}_{2}\right)$ and hydroxyl radicals $\left(\mathrm{OH}^{-}\right)$by a successive univalent reduction of oxygen $\left(\mathrm{O}_{2}\right)$ via chemical and enzymatic reactions (Asada, 1999; Apel and Hirt, 2004). Excessive ROS are potentially harmful to plant cells because of inactivating photosystem (PS) I and PS II (Jakob and Heber, 1996), and causing oxidative damage to proteins, lipids, and nucleic acids (Apel and Hirt, 2004). K. candel plants have an oxygen scavenging system against $\mathrm{ROS}$ under $\mathrm{NaCl}$ stress. Proteomic analysis of its leaves revealed that superoxide dismutase (SOD) abundance increased in response to high $\mathrm{NaCl}$ at 450-600 mM (Wang et al., 2014). SODs constitute the first line of cellular defense against ROS by rapidly converting $\mathrm{O}_{2}^{-}$and water to $\mathrm{H}_{2} \mathrm{O}_{2}$ and $\mathrm{O}_{2}$ (Bowler et al., 1992; Fridovich, 1995). Furthermore, SOD contributes to minimizing $\mathrm{OH}^{-}$formed by 
Haber-Weiss or Fenton reactions (Bowler et al., 1992; Gutteridge and Halliwell, 2010). Wang et al. (2013) found that abiotic-stress proteins were up-regulated by $\mathrm{NaCl}$ in $K$. candel chloroplasts. However, the protection of chloroplast $\mathrm{Cu} / \mathrm{Zn} \mathrm{SOD}$ (CSD) to salt tolerance is still poorly understood.

The objectives of this study were to investigate $\mathrm{Na}^{+}$uptake and transport in $K$. candel plants and antioxidative defense under increasing $\mathrm{NaCl}$ salinity. Alterations of $\mathrm{Na}^{+}$flux were recorded in young roots using a non-invasive ion flux technique. Transcriptional response of CSD to salinity was examined in $K$. candel leaves. Microarray analysis has shown that $\mathrm{NaCl}$ stress increases $K c C S D$ expression (Hou, 2010). To clarify the role of $K c C S D$ in salinity tolerance, $K c C S D$ gene of chloroplast from K. candel was cloned and transferred to Nicotiana tabacum, a model system for investigating novel genes in salt tolerance (Han et al., 2013; Shen et al., 2013). In wild-type (WT) tobacco and $K c C S D$-overexpressing lines, ROS accumulation in leaf cells and activities of SOD, catalase (CAT), and ascorbate peroxidase (APX) were examined under $100 \mathrm{mM} \mathrm{NaCl}$ stress. This study could provide scientific evidence of KcCSD protection for antioxidant defense in chloroplast.

\section{MATERIALS AND METHODS PLANT MATERIAL AND TREATMENTS}

Uniform mature hypocotyls of $K$. candel were obtained from Dongzhai Harbor in Hainan Province of China $\left(19^{\circ} 51^{\prime} \mathrm{N}\right.$, $110^{\circ} 24^{\prime} \mathrm{E}$ ). Uniform hypocotyls from the same tree were planted in 5-L pots containing sand. Potted plants were placed in a greenhouse at Beijing Forestry University and fertilized with halfstrength Hoagland's nutrient solution (Hoagland and Arnon, 1950) every 2 weeks at $20-25^{\circ} \mathrm{C}$ under a 12 -h daily photoperiod with $200-300 \mu \mathrm{mol} \mathrm{m}^{-2} \mathrm{~s}^{-1}$. Plants were $25-30 \mathrm{~cm}$ high and had four pair leaves after 3 months of culture (Supplementary Figure S1). These plants were raised in Hoagland's nutrient solution without the addition of $\mathrm{NaCl}$. Mangrove plants were in good physiological state since shoots and roots retained abundant salts (Li et al., 2008; Lu et al., 2013). NaCl treatment was started from $100 \mathrm{mM}$ and increased stepwise by $100 \mathrm{mM}$ weekly, until reaching $300 \mathrm{mM}$, which could avoid osmotic shock effects of $\mathrm{NaCl}$ saline on the plants (Li et al., 2008). $\mathrm{Na}^{+}$flux in roots was recorded weekly and ion concentrations in roots and shoots were measured at low $(100 \mathrm{mM})$ and high saline $(300 \mathrm{mM})$ treatments, respectively. $\mathrm{H}_{2} \mathrm{O}_{2}, C S D$ expression and SOD activity in leaves were measured after $8 \mathrm{~h}, 24 \mathrm{~h}$, and 1,2 , and 3 weeks of $\mathrm{NaCl}$ treatment. The second pair leaves were harvested, quickly frozen in liquid nitrogen, and used for quantitative real-time PCR assays, SOD activity, and $\mathrm{H}_{2} \mathrm{O}_{2}$ measurements.

\section{$\mathrm{Na}^{+}$FLUX RECORDING IN $K$. CANDEL ROOTS}

Steady-state fluxes of $\mathrm{Na}^{+}$were measured using non-invasive micro-test technique (NMT-YG-100, Younger USA LLC, Amherst, MA, USA). $\mathrm{Na}^{+}$microelectrodes were prepared and calibrated as previously described (Lu et al., 2013; Lang et al., 2014). Length of primary roots of $K$. candel seedlings ranged from 1 to $5 \mathrm{~cm}$ (Supplementary Figure S1). Young roots with apices of $2-3 \mathrm{~cm}$ were excised from control and salinized plants for $\mathrm{Na}^{+}$flux determination. Steady flux profiles of $\mathrm{Na}^{+}$were measured along the root axis at the apical zones, where a vigorous flux was usually observed in woody plants (Sun et al., 2009a,b; Lu et al., 2013; Lang et al., 2014). Roots were rinsed with redistilled water and immediately incubated in measuring solution (with $0.1 \mathrm{mM} \mathrm{Na}^{+}$) for 30 min equilibration. The basic $\mathrm{Na}^{+}$measuring solution (with low interfering ions of $\mathrm{Ca}^{2+}$ and $\mathrm{K}^{+}$, Cuin et al., 2011) was $0.1 \mathrm{mM} \mathrm{NaCl}, \mathrm{MgCl}_{2}$, and $\mathrm{CaCl}_{2}$, and $0.5 \mathrm{mM} \mathrm{KCl}$ at $\mathrm{pH}$ 6.0. Roots were immobilized on the bottom of the chamber. Then ion flux recordings started $200 \mu \mathrm{m}$ from the apex and conducted along root axis until $2000 \mu \mathrm{m}$ with an interval of 300 or $500 \mu \mathrm{m}$. Ionic flux rates were obtained using MageFlux developed by Yue Xu (1995) (http://www.youngerusa.com).

\section{ION ANALYSIS}

Roots, leaves, stems, and hypocotyls were harvested from control and $\mathrm{NaCl}$-stressed $K$. candel plants, and oven-dried to constant weight at $65^{\circ} \mathrm{C}$ for 4 days, ground and passed through a 1.0mm sieve. Samples were digested by $\mathrm{H}_{2} \mathrm{SO}_{4}-\mathrm{H}_{2} \mathrm{O}_{2}$, and $\mathrm{Na}^{+}$ concentration was measured using an atomic absorption spectrophotometer (Perkin-Elmer 2280, PerkinElmer, Inc., Wellesley Hills, MA, USA) (Lu et al., 2013).

\section{RNA EXTRACTION AND REAL-TIME PCR ANALYSIS}

Total RNA was extracted from $K$. candel leaves (the second pair leaves) with a modified hot borate method (Wan and Wilkins, 1994). This protocol is commonly used for isolating RNA from plant tissues rich in polyphenols and polysaccharides. For tobacco, total RNA was extracted from the 3rd-4th mature leaves from the top using the Total RNA Extraction Kit (QBio Technologies Inc.). The integrity of total RNA was determined by running samples on $1.0 \%$ formaldehyde agarose gels stained with ethidium bromide. The quantity/yield of total RNA was estimated spectrophotometrically at $230,260,280 \mathrm{~nm}$ (NanoDrop 2000 spectrophotometer, Thermo Scientific, Wilmington, USA). The first strand was synthesized from $2 \mu \mathrm{g}$ of total RNA using MMLV reverse transcriptase (Promega, Madison, USA) and oligo $\left(\mathrm{d}_{\mathrm{T}}\right){ }^{12-15}$ primer at $42^{\circ} \mathrm{C}$ for $1 \mathrm{~h}$. The real-time PCR conditions were $10 \mathrm{~min}$ at $95^{\circ} \mathrm{C}, 35$ cycles of $95^{\circ} \mathrm{C}$ for $30 \mathrm{~s}, 55^{\circ} \mathrm{C}$ for $30 \mathrm{~s}, 72^{\circ} \mathrm{C}$ for $30 \mathrm{~s}$, and $10 \mathrm{~min}$ at $72^{\circ} \mathrm{C}$. The primers used for KcCSD were $5^{\prime}$-ATTAGCAACTATGTTTCCCA- $3^{\prime}$ (forward), and 5' - CTACAACGGTGAATGTTC-3' (reverse). The real-time PCR data in K. candel were normalized against Tubulin: Tubulin -F, $5^{\prime}$ TGCCCAAGGATGTGAACG-3'; and Tubulin-R, 5'-CCATACC CTCACCCACAT- $3^{\prime}$. In tobacco, EF1 $\alpha$ was used as the internal control (forward, 5'-GCTGTGAGGGACATGCGTCAAA-3'; and reverse, 5'-GTAGTAGATCGCGAGTACCACCA-3').

The real-time PCR analysis was performed in a Real-time PCR System (MJ Opticon2 Bio-Rad). The relative level of expression was quantified using MJ Opticon Monitor software (Bio-Rad, Hercules, CA, USA). The expression of the target genes were normalized to the expression level of the reference gene (Tubulin in $K$. candel and EF1 $\alpha$ in tobacco) using the $2^{-\Delta \Delta \mathrm{C}_{\mathrm{T}}}$ method (Livak and Schmittgen, 2001).

\section{SEQUENCE ALIGNMENT AND PHYLOGENETIC TREE}

Full-length amino acid sequences of $\mathrm{Cu} / \mathrm{Zn}$ SOD were aligned using ClustalW2 online (http://www.ebi.ac.uk/Tools/msa/ 
clustalw2/). Amino acid sequences of chloroplast transit peptide were predicted by ChloroP (http://www.cbs.dtu.dk/ services/TargetP/; http://www.cbs.dtu.dk/services/ChloroP/) (Emanuelsson et al., 1999, 2007). Phylogenetic tree was generated using the Neighbor-Joining (NJ) method in MEGA version 6.0 software (bootstrap analysis with 1000 replicates). The accession numbers of $\mathrm{Cu} / \mathrm{Zn}$ SOD protein sequences used in multiple sequence alignment and phylogenetic analysis are provided in Supplementary Table S1.

\section{PLASMID CONSTRUCTS}

The open reading frame (ORF) of KcCSD (GenBank accession number KP143653) was amplified by PCR from $K$. candel cDNA using specific primers (forward, 5' -ATGCAAGCGGTAGTTGCG$3^{\prime}$; reverse, 5'-TAACACTGGTGTCAACCCAACAAC- $\left.3^{\prime}\right)$. The PCR fragment was first cloned into the vector pMD18-T (Takara, Dalian, China) and verified by sequencing. The ORF of KcCSD was released by digestion with EcoRI and HindIII and introduced into the expression vector, pCAMBIA2300, under the control of the constitutive cauliflower mosaic virus $35 \mathrm{~S}$ promoter.

\section{OVEREXPRESSION OF KcCSD IN TRANSGENIC TOBACCO LINES}

To further analyze the functions of KcCSD upon $\mathrm{NaCl}$ stress, KcCSD was transferred to tobacco plants via Agrobacteriummediated gene transfer. The pCAMBIA2300-KcCSD construct was transferred to a strain of Agrobacterium tumefaciens (LBA4404) with a freeze-thaw method. Tobacco was infected by the Agrobacterium tumefaciens using the leaf disc method (Horsch et al., 1985). The infected leaves were placed on MS medium (Murashige and Skoog, 1962) with no antibiotic for 2-3 days and transferred to MS with $50 \mathrm{mg} / \mathrm{L}$ kanamycin. Individual kanamycin-resistant shoots were selected and shooted on MS medium with no growth regulators or antibiotic. More than 10 independently transformed plants were selected for KcCSD expression assay. Those overexpressing KcCSD were used for further study (L7 and L8; Supplementary Figure S2). WT and $K c C S D$-overexpressed plants were kept in the greenhouse to yield seeds. Using PCR, T2 generation of L7 and L8 was checked for the presence of the KcCSD gene.

T2 generation seeds of wild-type (WT) and transgenic lines (L7 and L8) were germinated on MS medium for 7 days, then subjected to 0 or $150 \mathrm{mM} \mathrm{NaCl}$ for 7 days. Root length, survival rates, and $\mathrm{H}_{2} \mathrm{O}_{2}$ level in chloroplast were measured in WT and transgenic plants. The capacity to control ROS was compared between WT and transgene tobacco under $\mathrm{NaCl}$ stress. Four-weeks old rooted plants of WT and transgenic lines were transferred to 1/4 Hoagland's nutrient solution for 2-weeks acclimation, then exposed to 0 or $100 \mathrm{mM} \mathrm{NaCl}$ for 7 days. $\mathrm{O}_{2}^{-}$and $\mathrm{H}_{2} \mathrm{O}_{2}$ production, lipid peroxidation, and activity of antioxidant enzymes (SOD, CAT and APX), SOD isoenzymes were examined during $\mathrm{NaCl}$ treatment $(100 \mathrm{mM}, 7$ day). Leaf photosynthesis, chlorophyll a fluorescence, chlorophyll content were measured in $\mathrm{NaCl}$-stressed WT and transgenic plants.

\section{SUBCELLULAR LOCALIZATION OF THE GFP FUSION PROTEINS}

To generate a translational fusion of KcCSD-GFP, the KcCSD was obtained by PCR using specific primers (forward 5'-ATGCAAG
CGGTAGTTGCG-3'; reverse 5' - CACTGGTGTCAACCCAACA $\left.\mathrm{AC}-3^{\prime}\right)$. PCR products were cloned into the pMD18-T vector and sequenced. The resulting construct was digested by EcoRI and Pst I and introduced into the constructed pGreen0029-GFP vector driven by the $35 \mathrm{~S}$ promoter. Vector-carrying 35S-driven GFP was used as free GFP control.

KcCSD-GFP was transiently transformed to mesophyll protoplasts of Arabidopsis thaliana due to a high frequency of gene transformation, as compared to the tobacco. Isolation of Arabidopsis mesophyll protoplasts and polyethylene glycolmediated transformation were performed according to Yoo et al. (2007). Confocal images were obtained after $16-20 \mathrm{~h}$ of incubation. Fluorescence was examined with a Leica inverted fluorescence microscope (Leica Microsystems $\mathrm{GmbH}$ ) at $510-535 \mathrm{~nm}$ for GFP and at $650-750 \mathrm{~nm}$ for chlorophyll.

\section{MALONDIALDEHYDE (MDA) CONTENT}

Tobacco leaves $(0.1 \mathrm{~g}, 3 \mathrm{rd}-5$ th mature leaves from the top) were homogenized in $1 \mathrm{ml}$ of $0.1 \%$ trichloroacetic acid solution on ice. MDA content in WT and KcCSD-transgenic lines was determined by the thiobarbituric acid (TBA) reaction according to Heath and Packer (1968).

\section{CHLOROPHYLL CONTENT, FLUORESCENCE PARAMETERS, AND NET PHOTOSYNTHETIC RATE}

The 3rd-5th mature leaves from the top were used for chlorophyll contents, fluorescence, and photosynthesis measurements. Chlorophyll concentrations in WT and transgenic lines were measured according to Wellburn (1994) and Lichtenthaler (1987). Chlorophyll $a$ fluorescence parameters were measured using a PAM fluorometer (Junior PAM, Walz, Germany). Plants were dark-adapted for $20 \mathrm{~min}$ to determine dark fluorescence yield (Fo), and then exposed to a single red pulse to determine maximal fluorescence yield (Fm) and Fv/Fm ratio using the formula (Fm-Fo)/Fm. ФPSII, the PSII actual photochemical efficiency, was determined according to Wang et al. (2007). Net photosynthetic rate (Pn) was measured using a Li-6400 photosynthesis system (Li-Cor Inc., Lincoln, NE, USA) at $800 \mu \mathrm{mol}$ photons $\mathrm{m}^{-2} \mathrm{~s}^{-1}$. Chamber air temperature was maintained at $25^{\circ} \mathrm{C}$ and $\mathrm{CO}_{2}$ concentration was $380 \mu \mathrm{L} \mathrm{L}^{-1}$.

\section{TOTAL PROTEIN EXTRACTION AND ENZYME ASSAYS}

Antioxidant enzymes were extracted from $K$. candel (3rd-4th mature leaves from the top) and tobacco leaves (3rd-5th mature leaves from the top) and measured according to Wang et al. (2007, 2008). The total SOD activity was determined by monitoring super-radical-induced reduction of nitro blue tetrazolium (NBT) at $560 \mathrm{~nm}$ (Giannopolitis and Ries, 1977; Wang et al., 2008; Shen et al., 2013). One unit of SOD (relative unit) was defined as the amount of enzyme that causes $50 \%$ inhibition of the reaction compared with a blank sample (Giannopolitis and Ries, 1977). CAT activity was determined spectrophotometrically by monitoring the disappearance of $\mathrm{H}_{2} \mathrm{O}_{2}$ at $240 \mathrm{~nm}$ for $1 \mathrm{~min}$ (Aebi, 1984). APX activity was determined by monitoring the $\mathrm{H}_{2} \mathrm{O}_{2}$-dependent oxidation of ascorbate at $290 \mathrm{~nm}$ for $1.5 \mathrm{~min}$ (Nakano and Asada, 1981). 


\section{NATIVE PAGE OF SOD ISOENZYMES}

Salt-elicited alterations in SOD isoenzymes were examined after 7 days of $\mathrm{NaCl}$ treatment $(100 \mathrm{mM})$. SOD was extracted from transgenic and WT tobacco leaves (3rd-5th mature leaves from the top) at $4^{\circ} \mathrm{C}$ (Beauchamp and Fridovich, 1971; Wang et al., $2007,2008)$. Native PAGE of SOD was performed on a $7.5 \%$ separating gel and $3.9 \%$ stacking gel at $4^{\circ} \mathrm{C}$. After electrophoresis, the SOD isoenzymes were differentiated on a pre-equilibrating gel for $30 \mathrm{~min}$ in $50 \mathrm{mM}$ potassium phosphate buffer and $1 \mathrm{mM}$ EDTA at $\mathrm{pH}$ 7.8. The gel was incubated in dark for $30 \mathrm{~min}$ in fresh staining solution of $50 \mathrm{mM}$ potassium phosphate buffer ( $\mathrm{pH} 7.8$ ), $0.24 \mathrm{mM}$ NBT, $33.2 \mu \mathrm{M}$ riboflavin, and $0.2 \%$ tetramethylethylenediamine. Then it was illuminated with $400 \mu \mathrm{mol}$ $\mathrm{m}^{-2} \mathrm{~s}^{-1}$ fluorescence until uniformly blue except areas with SOD activity.

\section{$\mathrm{O}_{2}^{-}$AND $\mathrm{H}_{2} \mathrm{O}_{2}$ PRODUCTION IN LEAVES}

In situ accumulations of $\mathrm{O}_{2}^{-}$and $\mathrm{H}_{2} \mathrm{O}_{2}$ were examined with histochemical staining protocols. $\mathrm{O}_{2}^{-}$was detected with NBT (Dutilleul et al., 2003) and $\mathrm{H}_{2} \mathrm{O}_{2}$ with 3-3'-diaminobenzidine (DAB; Thordal-Christensen et al., 1997), respectively. For in situ staining of $\mathrm{O}_{2}^{-}$, leaf discs $(2 \mathrm{~cm}$ in diameter) were sampled from the second fully developed leaf on the top, and immediately vacuum infiltrated in $0.5 \mathrm{mg} / \mathrm{ml} \mathrm{NBT}$ and $10 \mathrm{mM}$ potassium phosphate buffer at $\mathrm{pH}$ 7.8. For the negative control, the NBT solution was supplemented with $10 \mathrm{U} \mathrm{ml}^{-1} \mathrm{SOD}$ and $10 \mathrm{mM}$ $\mathrm{MnCl}_{2}$ before the infiltration (Supplementary Figure S3). After being incubated in dark at room temperature for $1 \mathrm{~h}$, samples were cleared in $90 \%$ ethanol at $70^{\circ} \mathrm{C}$ to remove chlorophyll. $\mathrm{O}_{2}^{-}$ was visualized as a blue color at the site of NBT precipitation.

Leaf discs ( $2 \mathrm{~cm}$ in diameter) were vacuum infiltrated in $1 \mathrm{mg} / \mathrm{ml} \mathrm{DAB}$ at $\mathrm{pH} 3.8$, incubated in dark at room temperature for $14 \mathrm{~h}$ and transferred to $90 \%$ ethanol at $70^{\circ} \mathrm{C}$ until complete removal of chlorophyll and visualization of $\mathrm{H}_{2} \mathrm{O}_{2}$ as brown color at the site of DAB polymerization. Samples were stored and examined in $70 \%$ glycerol. For the negative control, $10 \mathrm{mM}$ ascorbic acid was added into DAB solution for infiltration. Total leaf $\mathrm{H}_{2} \mathrm{O}_{2}$ was determined according to Wang et al. (2008).

\section{$\mathrm{H}_{\mathbf{2}} \mathrm{O}_{2}$ DETECTION IN CHLOROPLAST}

$\mathrm{H}_{2} \mathrm{O}_{2}$ in chloroplast was detected as described by Ramírez et al. (2013) with minor modifications. $\mathrm{H}_{2} \mathrm{O}_{2}$-specific fluorescent probe, $\mathrm{H}_{2}$ DCF-DA, was an indicator of $\mathrm{H}_{2} \mathrm{O}_{2}$ (Sun et al., 2010a,b, 2012). WT and KcCSD-transgenic tobacco seedlings were germinated on MS for 7 days, then transferred to MS supplemented with 0 or $150 \mathrm{mM} \mathrm{NaCl}$. Seedlings were vacuum infiltrated for $10 \mathrm{~min}$ in $10 \mu \mathrm{M} \mathrm{H}_{2}$ DCF-DA (Sigma Aldrich) in $5 \mathrm{mM} \mathrm{MES}$ buffer at $\mathrm{pH}$ 5.7. After being incubated in dark for $20 \mathrm{~min}$, leaf samples were washed with $5 \mathrm{mM}$ MES for $30 \mathrm{~min}$. Fluorescence was examined with a Leica inverted fluorescence microscope (Leica Microsystems $\mathrm{GmbH}$ ) at 500-530 $\mathrm{nm}$ for $\mathrm{H}_{2}$ DCF-DA and 650-750 nm for chlorophyll, respectively.

\section{STATISTICAL ANALYSIS}

All experimental data were subjected to SPSS (SPSS Statistics $17.0,2008)$ for statistical tests and analyses. When $P<0.05$,
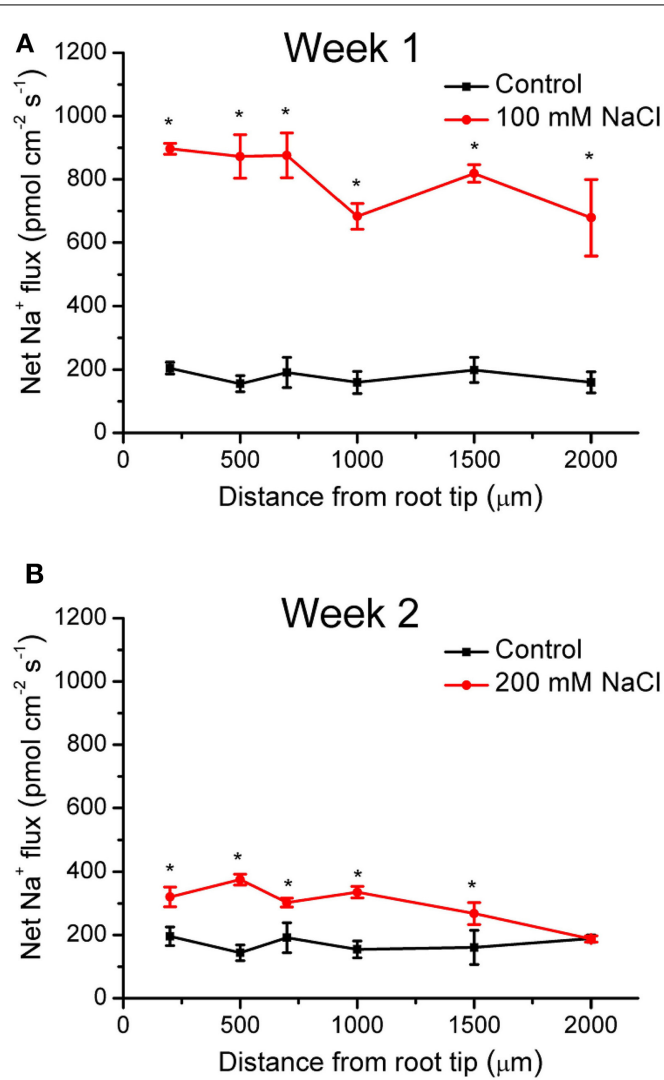

C

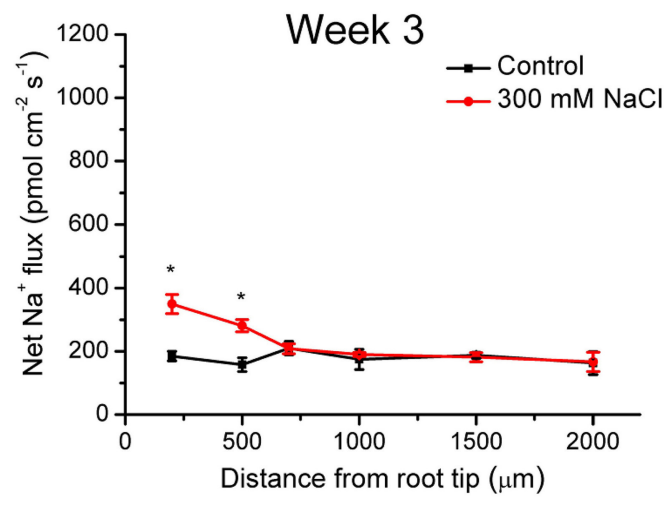

FIGURE 1 | Effects of $\mathrm{NaCl}$ on net $\mathrm{Na}^{+}$fluxes in young roots of K. candel. Plants were treated by a rising $\mathrm{NaCl}$ concentration from 100 to $300 \mathrm{mM}$ weekly for 3 weeks. The control was not exposed to $\mathrm{NaCl}$. Steady $\mathrm{Na}^{+}$flux profiles on week 1 (A), week 2 (B), and week 3 (C) were determined along root axis at apical zones, 200-2000 $\mu \mathrm{m}$ from the tip. Each point is the mean of 4-6 replicates. Bars represent standard error of the mean. ${ }^{*} P<0.05$, control and $\mathrm{NaCl}$ treatment.

differences between means were considered significant unless otherwise stated.

\section{RESULTS}

\section{$\mathrm{Na}^{+}$FLUX AND $\mathrm{Na}^{+}$CONCENTRATIONS IN ROOTS AND SHOOTS}

During $\mathrm{NaCl}$ treatment, $\mathrm{Na}^{+}$flux of $K$. candel was recorded along the root axes (200-2000 $\mu \mathrm{m}$ from the apex), in which a 
vigorous flux of $\mathrm{Na}^{+}$was usually observed. Under control conditions, $K$. candel roots exhibited a stable and constant $\mathrm{Na}^{+}$efflux with a mean flux of $176 \mathrm{pmol} \mathrm{cm} \mathrm{cm}^{-2} \mathrm{~s}^{-1}$ (Figure 1). The $\mathrm{Na}^{+}$ efflux in control plants was due to $\mathrm{Na}^{+}$previously accumulated by roots (Figure 2 ). However, $\mathrm{Na}^{+}$efflux along roots was significantly increased by 4.5 -fold in the first week of $\mathrm{NaCl}$ exposure (Figure 1). Flux rate in $\mathrm{NaCl}$-stressed roots remarkably decreased with the extension of the exposure (Figure 1). The mean $\mathrm{Na}^{+}$ efflux in salinized roots was only $30 \%$ higher than the controls in the third week (Figure 1).

$\mathrm{Na}^{+}$content in roots, hypocotyls, stems, and leaves significantly rose after 3 weeks treatment. It was 54-400\% higher than that in the control (Figure 2). The $\mathrm{Na}^{+}$accumulation was more pronounced in roots than in shoots (Figure 2).

\section{NaCl-ELICITED $\mathrm{H}_{2} \mathrm{O}_{2}$, SOD ACTIVITY AND EXPRESSION OF KcCSD}

$\mathrm{NaCl}$ salinity increased $\mathrm{H}_{2} \mathrm{O}_{2}$ levels in $K$. candel leaves although $\mathrm{H}_{2} \mathrm{O}_{2}$ levels fluctuated during 3 weeks experiment (Figure 3).

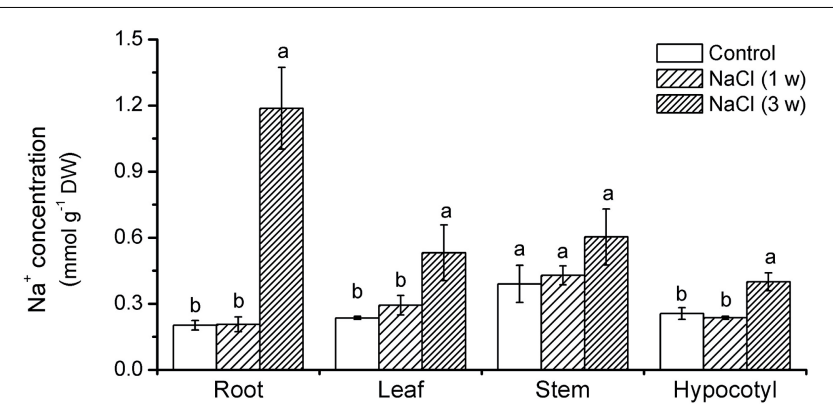

FIGURE 2 | Effects of $\mathrm{NaCl}$ on $\mathrm{Na}^{+}$concentrations in roots and shoots in $\boldsymbol{K}$. candel. Plants were treated by a rising $\mathrm{NaCl}$ concentration from 100 to $300 \mathrm{mM}$ weekly for 3 weeks. Each column is the mean of 4-6 replicates. Bars represent standard error of the mean. Different letters denote significant differences at $P<0.05$ between treatments in each organ.
Salinized K. candel enhanced SOD activity in its leaves (Figure 3). Quantitative real-time PCR (qRT-PCR) showed KcCSD upregulation during $\mathrm{NaCl}$ treatment (Figure 3). These results indicate a molecular and biochemical change in expression of KcCSD in salinized K. candel.

\section{KcCSD CLONING AND SEQUENCE ANALYSIS}

The cDNA sequence of KcCSD contains $687 \mathrm{bp}$ with a predicted open reading frame (ORF) of 228 amino acids (Figure 4A). KcCSD protein conserves $\mathrm{Cu}^{2+}$ or $\mathrm{Zn}^{2+}$ binding site and active site (amino acids from 84 to 219), which catalyzes the conversion of $\mathrm{O}_{2}^{-}$to $\mathrm{O}_{2}$ (Figure 4A). It also contains a chloroplast transit peptide with a potential cleavage site at amino acid position 73 (Figure 4A). Comparative phylogenetic analysis of KcCSD has revealed that KcCSD is homologous to Arabidopsis CSD2 and other chloroplast CSDs from different species (Figure 4B). Collectively, KcCSD can be classified as CSD2, a chloroplasttargeted protein.

\section{SUBCELLULAR LOCATION OF KcCSD}

A C-terminal translational construct was generated by the fusion of $K c C S D$ to the green fluorescent protein (GFP) reporter gene. The construct was transiently expressed in Arabidopsis protoplasts (Figure 5). Fluorescence emitted by the GFP fusion of KcCSD overlapped chlorophyll autofluorescence, revealing that KcCSD was targeted to the chloroplast (Figures 5D-F). Fluorescence of the free GFP under the control of 35 S promoter was distributed in cytoplasm of protoplasts, not merging with red autofluorescence from chloroplast (Figures 5A-C).

\section{SALINITY TOLERANCE OF KcCSD-TRANSGENIC TOBACCO PLANTS}

Analysis by qRT-PCR identified a strong overexpression of $\mathrm{KcCSD}$ in the transgenic lines L1, L7, L8, and L10, but KcCSD was not detectable in the WT plants (Supplementary Figure S2). L7 and L8 transgenic lines showed a remarkably higher transcript abundance, indicating that KcCSD driven by the $35 \mathrm{~S}$ promoter

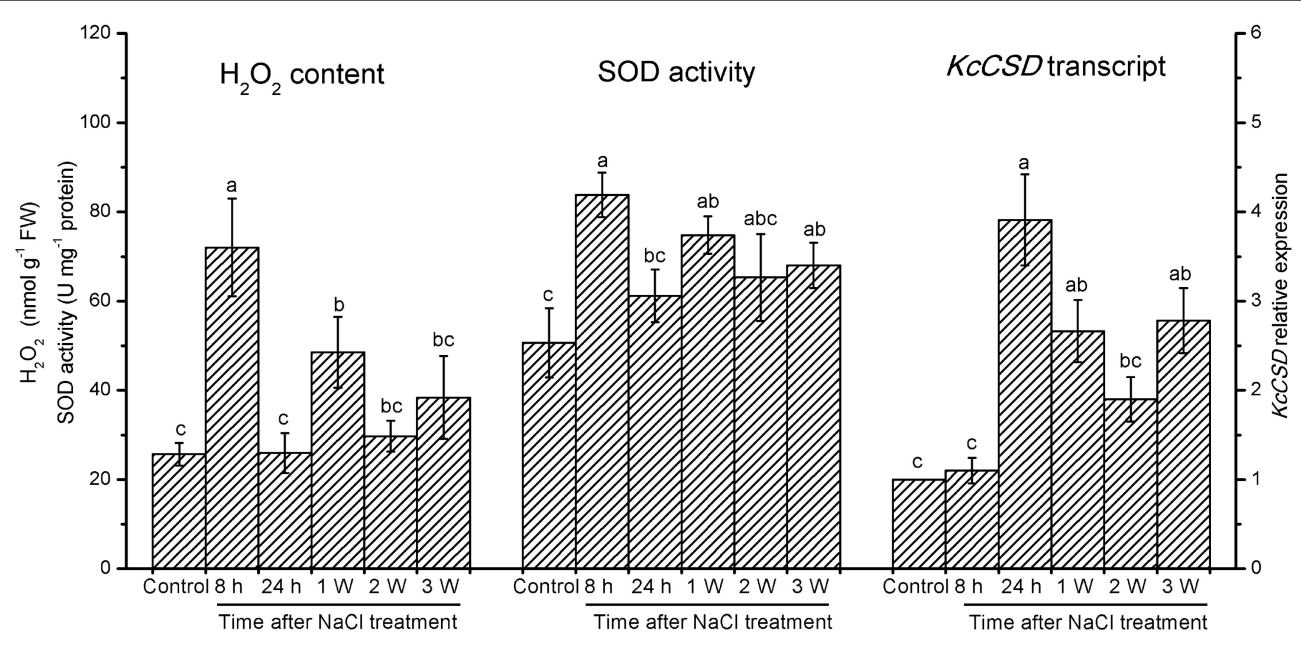

FIGURE 3 | Total concentration of $\mathrm{H}_{2} \mathrm{O}_{2}$, total SOD activity, and $K c C S D$ expression in $\boldsymbol{K}$. candel leaves under rising $\mathrm{NaCl}$ stress. Plants were treated by a rising $\mathrm{NaCl}$ concentration from 100 to $300 \mathrm{mM}$ weekly for 3 weeks. Each column is the mean of 4-6 replicates. Bars represent standard error of the mean. Different letters above columns represent significant differences at $P<0.05$ during treatment. 


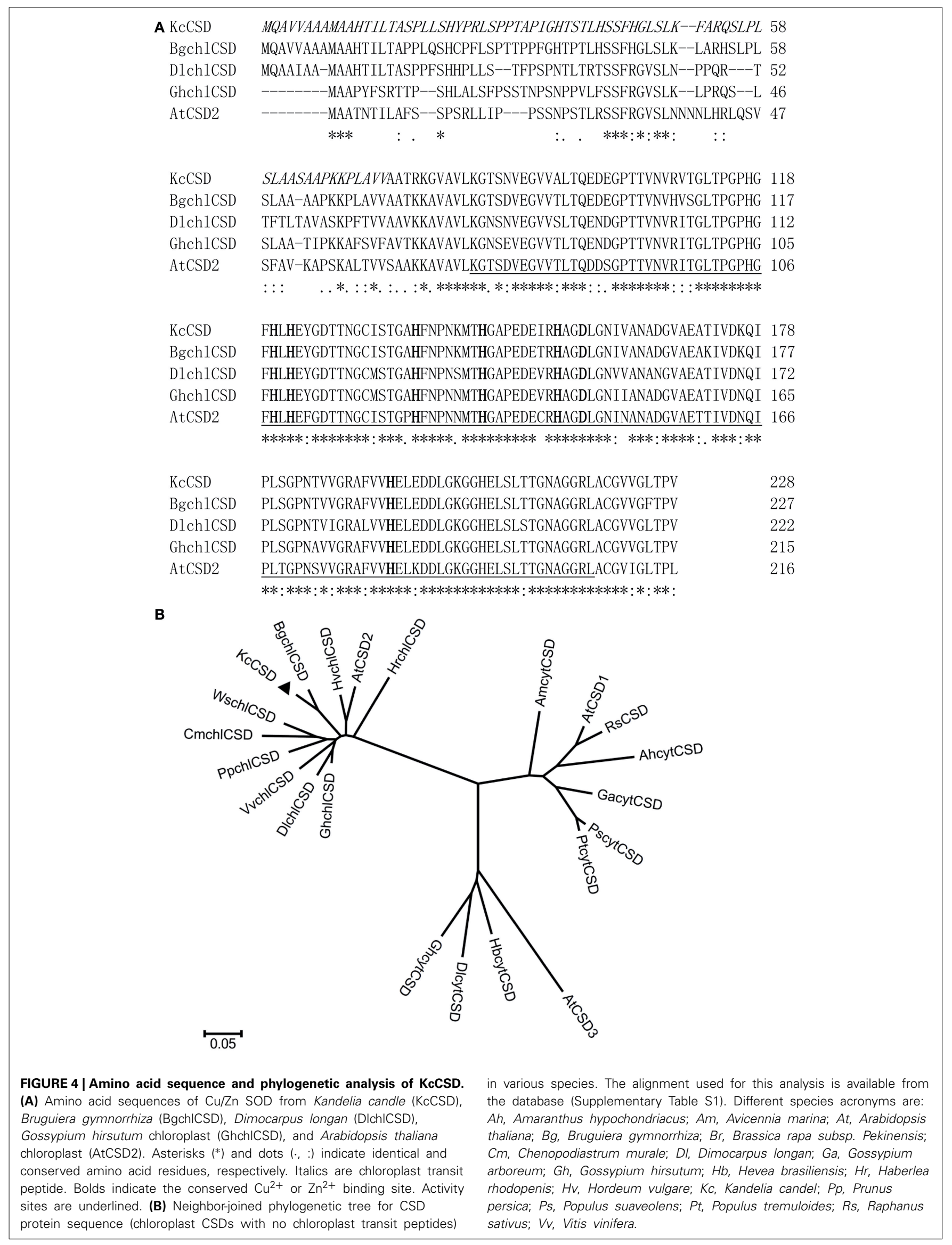


was more efficiently expressed in these lines, as compared to other ones. To testify the importance of KcCSD in enhancing $\mathrm{NaCl}$ tolerance, L7 and L8 were used for further $\mathrm{NaCl}$ treatment studies.

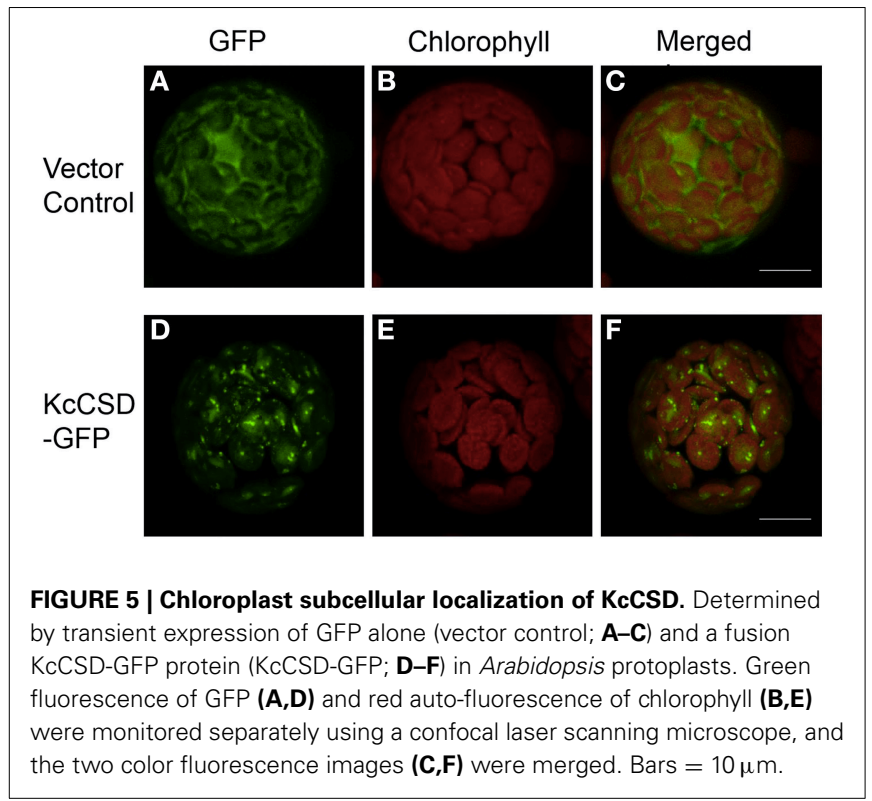

$\mathrm{NaCl}$ treatment ( $150 \mathrm{mM}, 7$ day) inhibited root growth and survival rate, but a more pronounced reduction occurred in WT (Figures 6A,C,D). Under hydroponic culture, WT plants showed a significant growth retardation compared to transgenic lines during a prolonged treatment (14 days; Figure 6B). Net photosynthetic rate $(\mathrm{Pn})$ was decreased in WT and transgenic plants by salinity (Figure 6E). However, Pn was 7493\% higher in transgenic lines than in WT plants (Figure 6E). Under non- $\mathrm{NaCl}$ stress, both root and shoot growth of transgenic plants did not significantly differ from WT ones (Figure 6).

\section{CHLOROPHYLL CONTENT AND FLUORESCENCE}

$\mathrm{NaCl}$ treatment $(100 \mathrm{mM})$ for 7 days resulted in a chlorophyll decline in tobacco plants (Figure 7A). However, it was more pronounced in WT than in transgenic lines L7 and L8 (Figure 7A). $\mathrm{NaCl}$ caused a decline in the chlorophyll a/b ratio by $14 \%$ in WT, which was greater than that in transgenic lines (Figure 7B).

After $100 \mathrm{mM} \mathrm{NaCl}$ treatment for a week, Fv/Fm was lowered in tobacco plants, but a more significant effect was observed in the WT ones (Figure 7C). $\Phi$ PSII, PSII actual photochemical efficiency (Maxwell and Johnson, 2000), in WT plants decreased remarkably by $\mathrm{NaCl}$ stress (Figure 7D). There was no similar change in KcCSD-transgenic lines (Figure 7D).
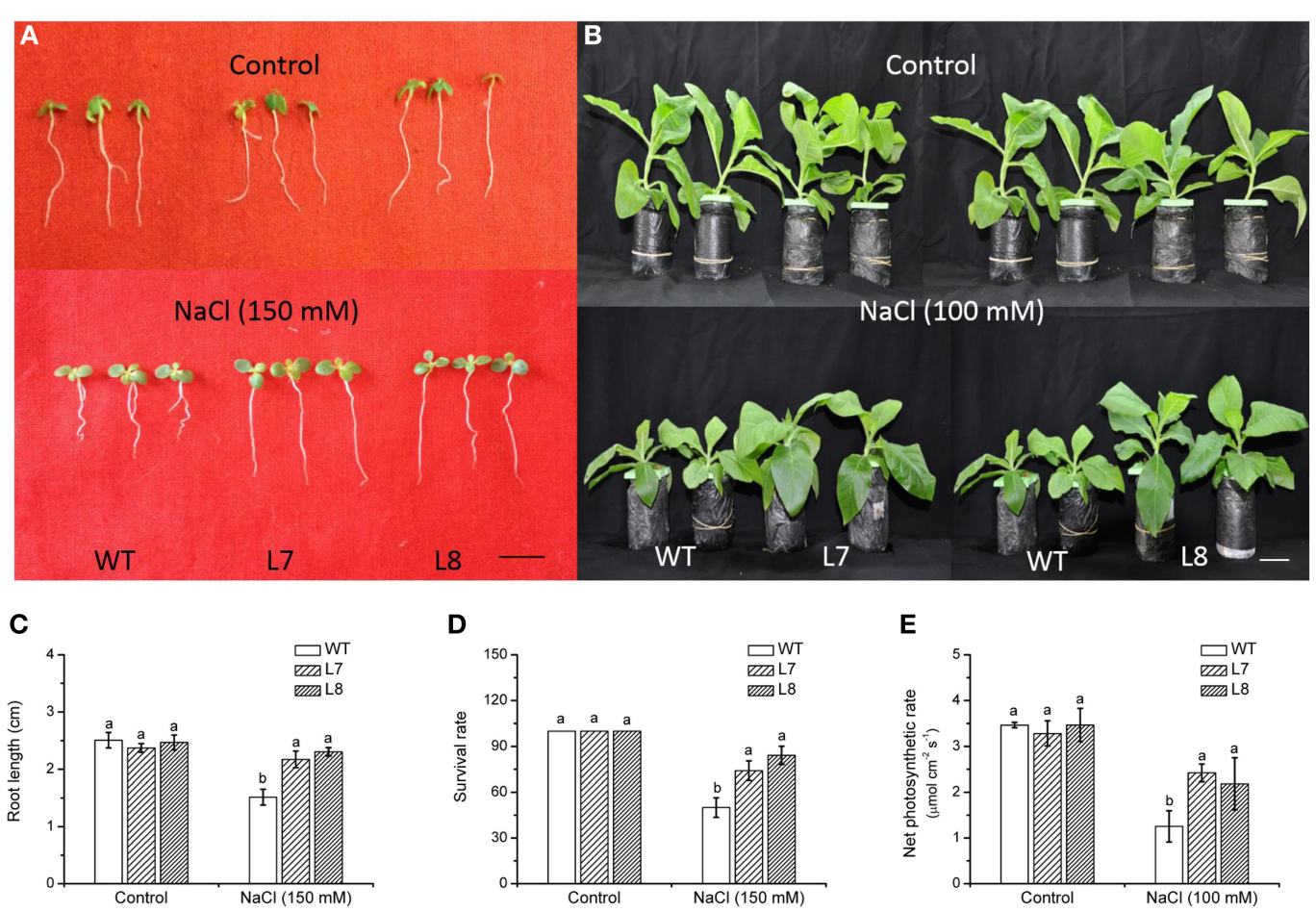

FIGURE 6 | $\mathrm{NaCl}$ tolerance of wild-type tobacco and $K \boldsymbol{c C S D}$-transgenic lines. Seeds of wild-type (WT) and transgenic lines (L7 and L8) were germinated on MS medium for 7 days, then supplemented with 0 or $150 \mathrm{mM}$ $\mathrm{NaCl}$ for another 7 days. (A,C,D) Show root growth and survival rate of tobacco seedlings. (B,E) Show plant performance and net photosynthetic rate of tobacco plants after exposure to 0 or $100 \mathrm{mM} \mathrm{NaCl}$ for 7 (E) or 14 (B) days. Prior to $\mathrm{NaCl}$ treatment, 4-weeks old rooted plants of WT and transgenic lines were transferred to $1 / 4$ Hoagland's nutrient solution for 2-weeks acclimation. In (C-E), each column is the mean of 4-6 replicates. Bars represent standard error of the mean. Different letters above columns represent significant differences at $P<0.05$ between WT and transgenic lines in control and $\mathrm{NaCl}$ treatments. Scale bars: $\mathrm{A}: 0.5 \mathrm{~cm}, \mathrm{~B}: 5 \mathrm{~cm}$. 


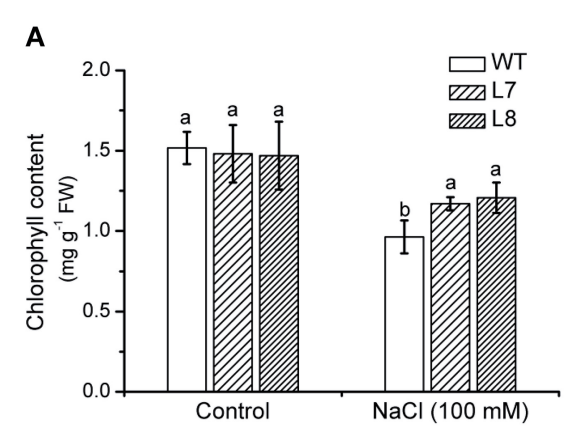

C

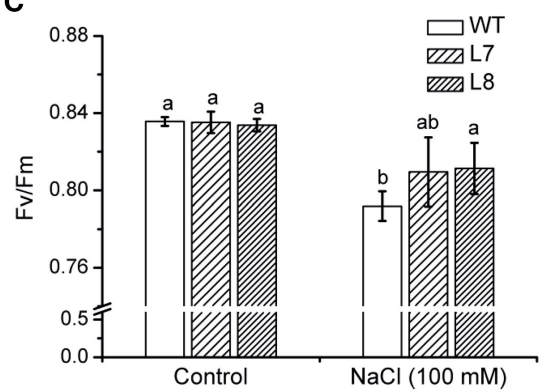

FIGURE 7 | Effects of $\mathrm{NaCl}$ on chlorophyll content and fluorescence in wild-type tobacco and $\boldsymbol{K} \boldsymbol{c} \boldsymbol{C S D}$-transgenic lines. Four-weeks old rooted plants of wild-type (WT) and transgenic lines (L7 and L8) were transferred to $1 / 4$ Hoagland's nutrient solution for 2-weeks acclimation, then exposed to 0 or $100 \mathrm{mM} \mathrm{NaCl}$ for 7 days. (A) Chlorophyll content, (B) Chlorophyll a/b ratio,
B

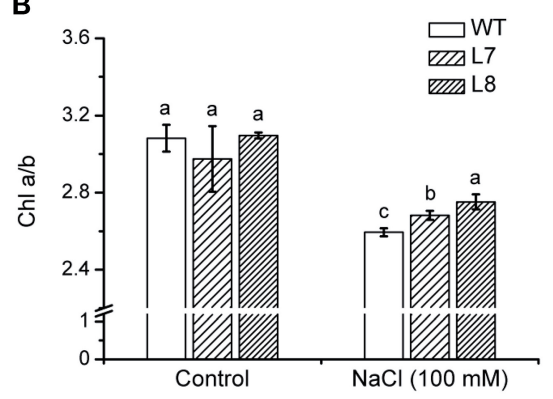

D

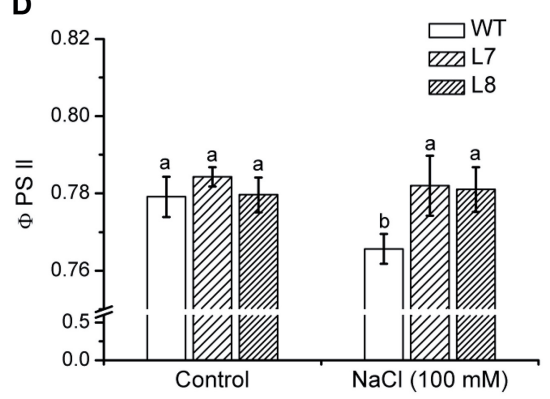

(C) Ratio of variable to maximal chlorophyll fluorescence (Fv/Fm), (D) Actual photochemical efficiency of PSII (TPSII). Each column is the mean of 4-6 replicates. Bars represent standard error of the mean. Different letters above columns represent significant differences at $P<0.05$ between WT and transgenic lines in control and $\mathrm{NaCl}$ treatments.
A

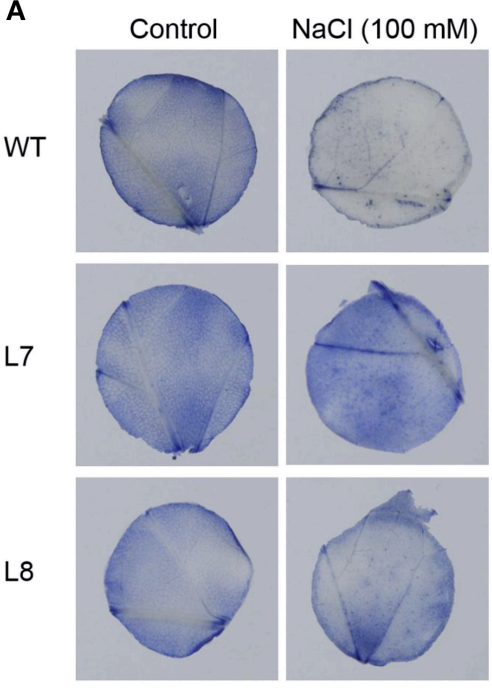

B

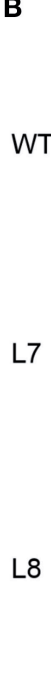

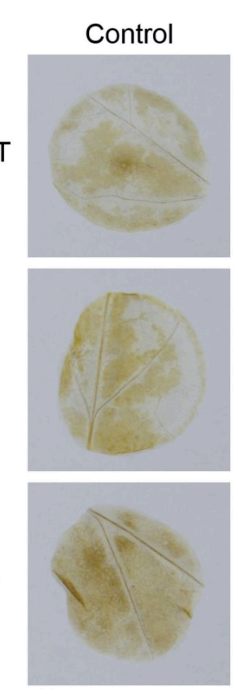

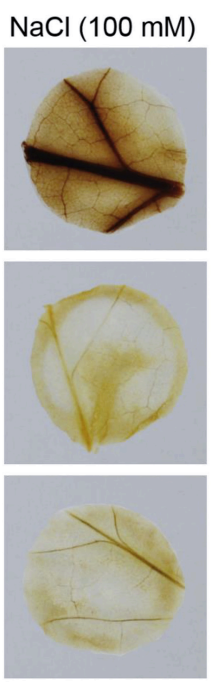

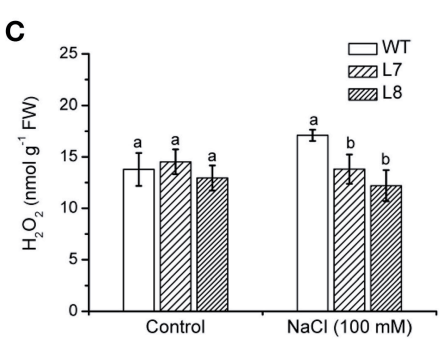

D

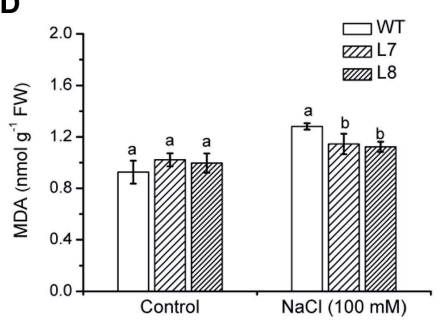

FIGURE 8 | Effects of $\mathrm{NaCl}$ on leaf ROS and malondialdehyde levels in wild-type tobacco and $K \boldsymbol{c} C S D$-transgenic lines. Four-weeks old rooted plants of wild-type (WT) and transgenic lines (L7 and L8) were transferred to $1 / 4$ Hoagland's nutrient solution for 2-weeks acclimation, then exposed to 0 or $100 \mathrm{mM} \mathrm{NaCl}$ for 7 days. Leaf discs $(2 \mathrm{~cm}$ in diameter) were sampled. (A)
In situ $\mathrm{O}_{2}^{-}$, (B) In situ $\mathrm{H}_{2} \mathrm{O}_{2}$, (C) Total $\mathrm{H}_{2} \mathrm{O}_{2}$, and (D) Malondialdehyde (MDA) content. In (C,D), each column is the mean of $4-6$ replicates. Bars represent standard error of the mean. Different letters above columns represent significant differences at $P<0.05$ between WT and transgenic lines in control and $\mathrm{NaCl}$ treatments. 


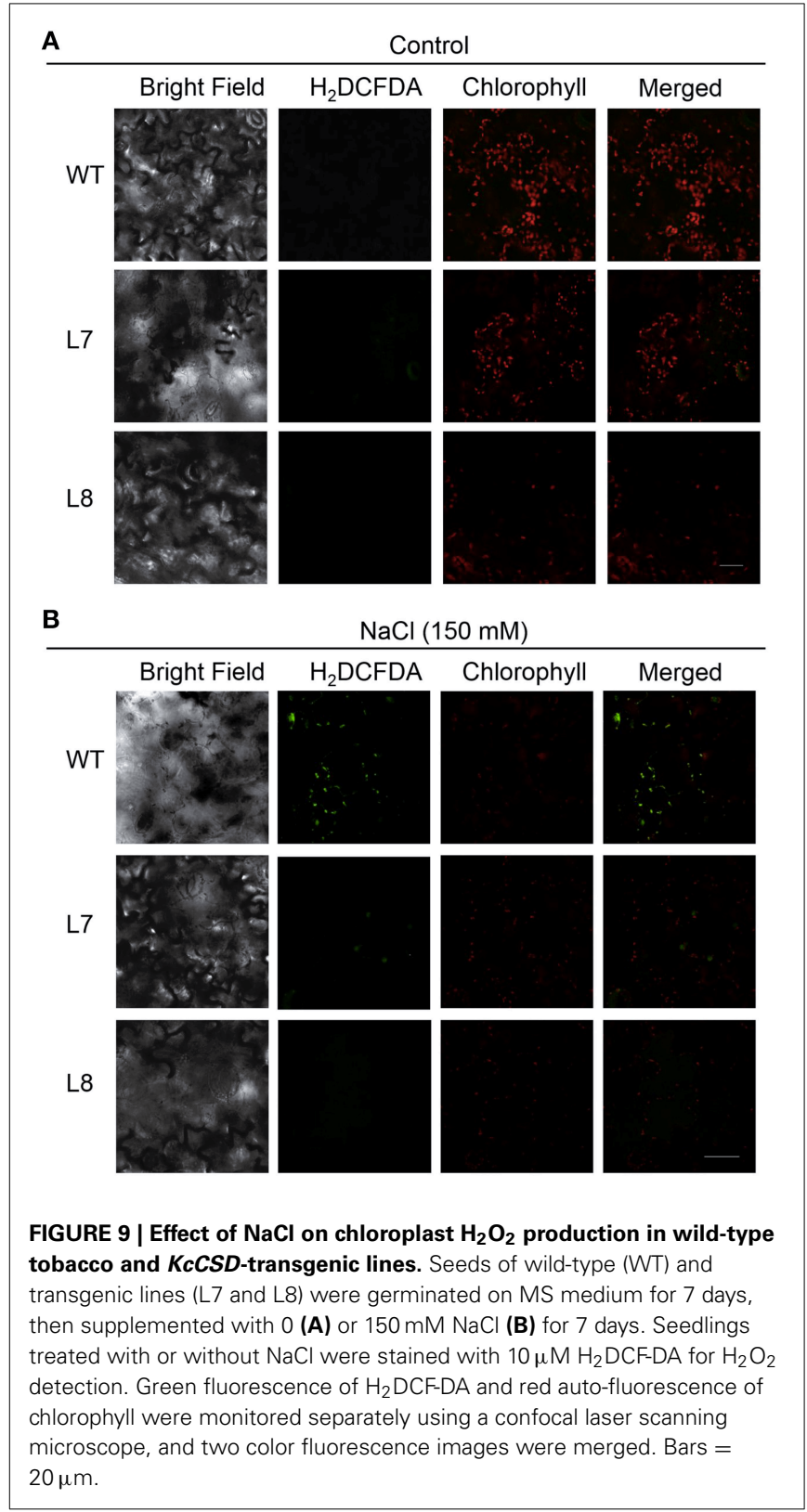

\section{$\mathrm{O}_{\mathbf{2}}^{-}$AND $\mathrm{H}_{\mathbf{2}} \mathrm{O}_{\mathbf{2}}$ PRODUCTION IN TOBACCO LEAVES}

In situ $\mathrm{O}_{2}^{-}$production in leaves was detected by the reduction of nitro blue tetrazolium (NBT). Formazan deposits were visualized in leaf discs of WT and transgenic lines under no- $\mathrm{NaCl}$ conditions (Figure 8A). After 1 week exposure to $100 \mathrm{mM} \mathrm{NaCl}$, more formazan precipitates appeared in tobacco leaves, especially in transgenic plants (Figure 8A). However, formazan formation in WT and KcCSD-transgenic plants was suppressed by SOD, the scavenger of $\mathrm{O}_{2}^{-}$, irrespective of $\mathrm{NaCl}$ and control treatments (Supplementary Figure S3). This indicates that NBT was reduced to formazan specifically by the superoxide anions in WT and KcCSD-transgenic plants.

By means of DAB staining, $\mathrm{H}_{2} \mathrm{O}_{2}$ levels were visible in $\mathrm{WT}$ and $\mathrm{KcCSD}$-transgenic lines (Figure 8B). Compared to the control, the intensity of red-brown staining significantly increased in

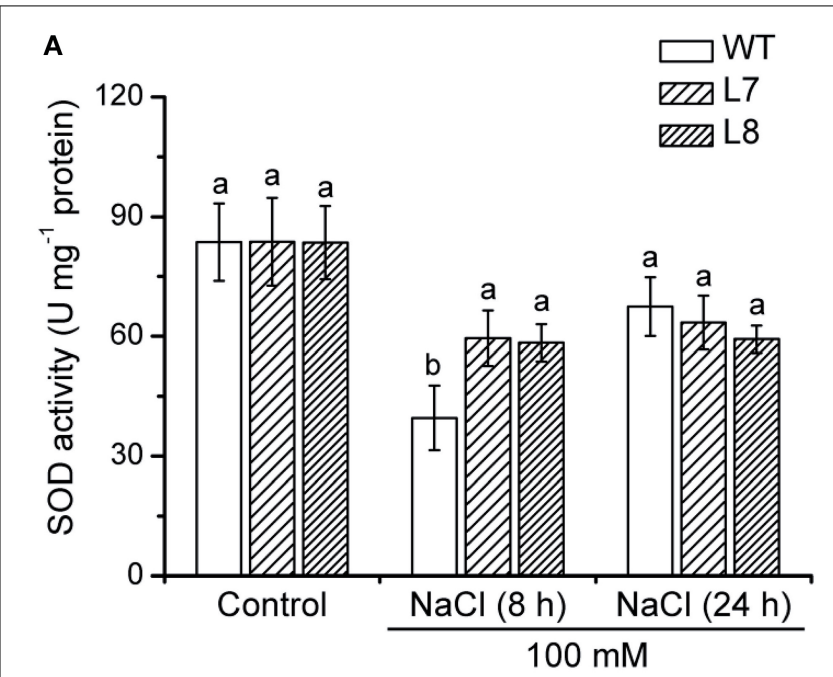

B

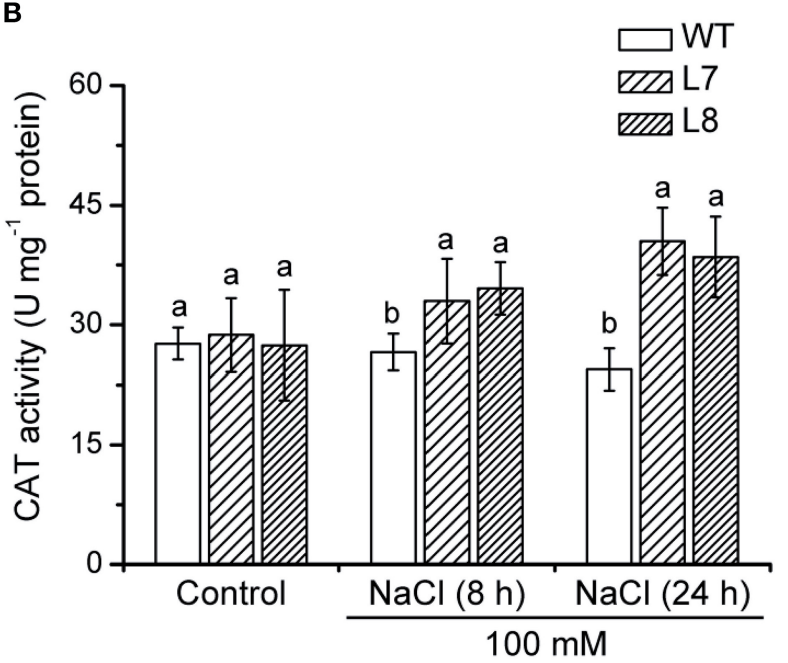

C

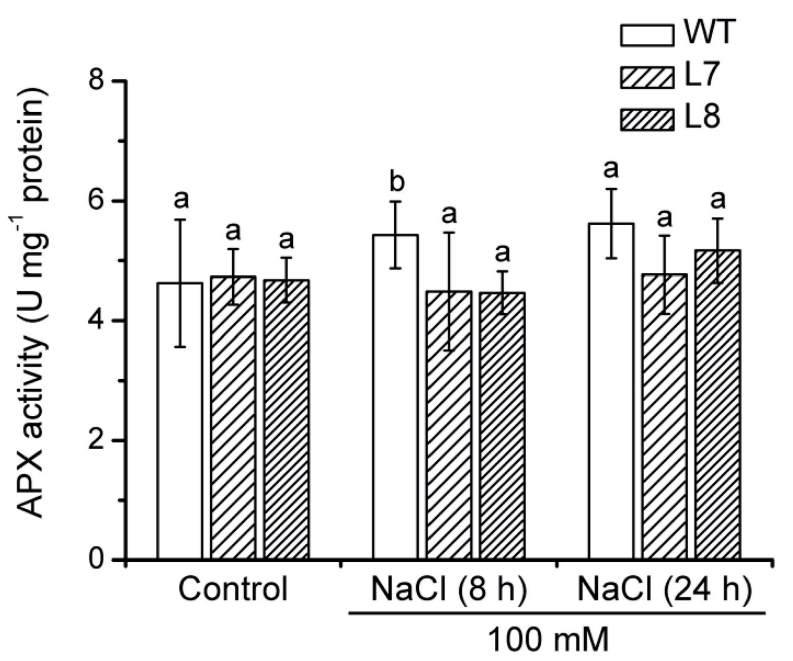

FIGURE 10 | Effect of $\mathrm{NaCl}$ on activities of antioxidant enzymes in wild-type tobacco and $\boldsymbol{K} \boldsymbol{c} \boldsymbol{C S D}$-transgenic lines. Four-weeks old rooted plants of wild-type (WT) and transgenic lines (L7 and L8) were transferred (Continued) 


\section{FIGURE 10 | Continued}

to $1 / 4$ Hoagland's nutrient solution for 2-weeks acclimation. Hydroponically acclimated plants were subjected to 0 or $100 \mathrm{mM} \mathrm{NaCl}$ for $24 \mathrm{~h}$. (A) Total

SOD activity, (B) CAT activity, and (C) APX activity. Each column is the mean of 4-6 replicates. Bars represent standard error of the mean. Different letters above columns represent significant differences at $P<0.05$ between wild-type and transgenic lines in control and $\mathrm{NaCl}$ treatments.

$\mathrm{NaCl}$-treated plants, and a more pronounced effect was observed in WT plants (Figure 8B). However, red-brown staining was absent in ascorbic acid-pretreated leaves (data not shown), indicating that the brownish staining was due to the reaction of $\mathrm{DAB}$ with $\mathrm{H}_{2} \mathrm{O}_{2}$. Total leaf $\mathrm{H}_{2} \mathrm{O}_{2}$ analysis showed a trend similar to that of in situ detection. $\mathrm{H}_{2} \mathrm{O}_{2}$ content in WT plants was increased by $16 \%$ under $\mathrm{NaCl}$ treatment, significantly higher than that in transgenic lines (Figure 8C).

\section{MDA CONTENT IN LEAVES}

$\mathrm{NaCl}$-elicited increase in MDA, a marker of lipid peroxidation, was observed in both WT tobacco and KcCSD-transgenic lines (Figure 8D). However, WT showed 34\% increase in MDA compared to transgenic lines L7 and L8 (10 and 17\%; Figure 8D). This indicates that $\mathrm{NaCl}$ caused a more pronounced oxidative damage in WT than in transgene plants.

\section{$\mathrm{H}_{2} \mathrm{O}_{2}$ LEVEL IN CHLOROPLASTS}

Confocal laser scanning microscopy analysis of leaf epidermal cells showed the same level of chlorophyll red auto-fluorescence in the WT tobacco and transgenic lines of the control (Figure 9A). In $\mathrm{NaCl}$ treatment, DCF-dependent green fluorescence occurred in $\mathrm{NaCl}$-stressed tobacco plants (Figure 9B). WT plants had a higher fluorescent intensity than the transgenic lines (Figure 9B). Furthermore, the green fluorescence overlapped the red autofluorescence (Figure 9B), indicating that the NaCl-elicited $\mathrm{H}_{2} \mathrm{O}_{2}$ mainly originated from chloroplast. Excessive $\mathrm{H}_{2} \mathrm{O}_{2}$ accumulation in chloroplast would cause oxidative damage to WT leaves.

\section{ACTIVITY OF ANTIOXIDANT ENZYMES}

In control conditions, SOD, CAT, and APX activities were similar in WT tobacco and transgenic plants (Figure 10). CAT and SOD activities of KcCSD-transgenic lines L7 and L8 were 20 and $50 \%$ higher than in WT after $8 \mathrm{~h}$ of $\mathrm{NaCl}$ stress, respectively (Figures 10A,B). Moreover, transgenic plants displayed a significantly higher CAT activity than WT plants after $24 \mathrm{~h}$ stress (Figure 10B), indicating that the capacity to scavenge $\mathrm{H}_{2} \mathrm{O}_{2}$ was enhanced by $\mathrm{NaCl}$ treatment. $\mathrm{NaCl}$ did not significantly decrease APX activity in WT and transgenic lines during short salinity (Figure 10C).

A 7-day $100 \mathrm{mM} \mathrm{NaCl}$ treatment increased activity of two dominant SOD isoenzymes in both transgenic lines and WT plants (Figure 11). Transgenic plants exhibited a higher increase in activity of one of four SOD isoenzymes than WT plants did under $\mathrm{NaCl}$ stress (arrowhead, Figure 11), indicating that overexpression of KcCSD in tobacco led to an increased antioxidant defense.

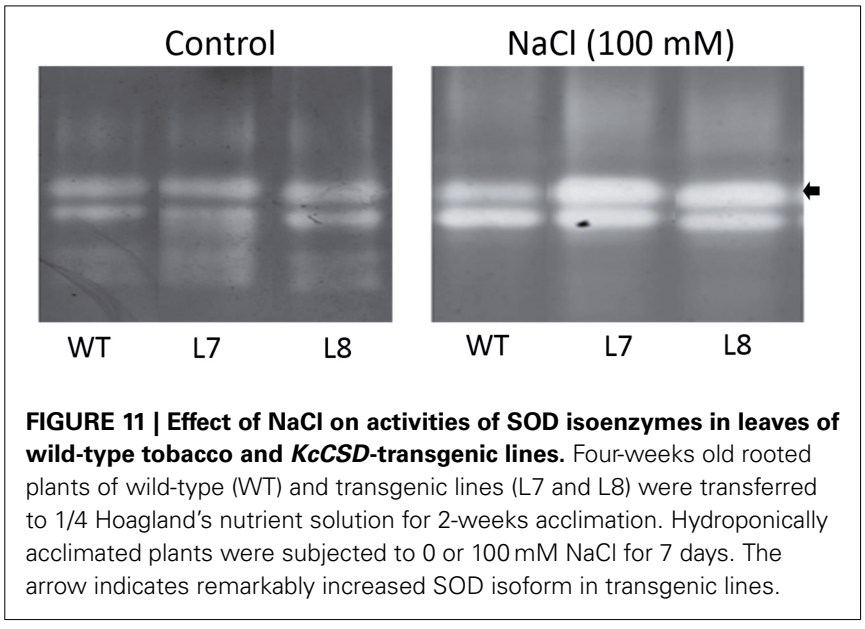

\section{DISCUSSION}

\section{$\mathrm{Na}^{+}$ACCUMULATION AND UPREGULATION OF KcCSD IN $K$. CANDEL LEAVES}

Young roots of $K$. candel had a net $\mathrm{Na}^{+}$efflux under rising $\mathrm{NaCl}$ stress from 100 to $300 \mathrm{mM}$ (Figure 1), which agreed with previous results in mangrove (Lu et al., 2013; Lang et al., 2014). Root $\mathrm{Na}^{+}$efflux resulted from active $\mathrm{Na}^{+} / \mathrm{H}^{+}$antiport across the PM (Lu et al., 2013; Lang et al., 2014). Root $\mathrm{Na}^{+}$exclusion was more pronounced in a short treatment (1 week) than in a long-term stress (2-3 weeks) (Figure 1). This indicates that $\mathrm{Na}^{+}$ extrusion capacity in $K$. candel roots declined with the exposure. As a result, large amount of $\mathrm{Na}^{+}$accumulated in roots was transported to other organs (hypocotyl, stem, and leaf) (Figure 2). Excessive $\mathrm{Na}^{+}$accumulation in $K$. candel leaves led to an increase of ROS (Figure 3). This was tallied with the findings in poplars (Wang et al., 2007, 2008). A limit in oxidative damage to photosynthetic apparatus and antioxidant enzyme activities could benefit for detoxifying $\mathrm{Na}^{+}$-elicited ROS in Populus euphratica (Wang et al., 2007, 2008). In the present work, salinized K. candel promoted KcCSD expression and subsequently enhanced SOD activity in leaves (Figure 3). Protein abundance of SOD in K. candel leaves might increase under a high level of $\mathrm{NaCl}$ (Wang et al., 2014). Thus, it could be inferred that $K$. candel would upregulate the antioxidant enzymes to deal with a long-term saline stress. To investigate the role of KcCSD in salinity tolerance, KcCSD gene was transferred to the model species Nicotiana tabacum. The transgenic tobacco overexpressing $K c C S D$ resulted in a greater root length and survival rate than WT plants under $\mathrm{NaCl}$ stress (Figure 6). This finding is consistent with other studies on transgenic Chinese cabbage plants (Tseng et al., 2007). Rice plants overexpressing a cytosolic Cu/Zn SOD gene (Avicennia marina) also conferred salinity tolerance in transgene plants (Prashanth et al., 2008). In this study, KcCSD overexpression in tobacco reduced ROS in chloroplasts under $\mathrm{NaCl}$ stress. The results confirmed the protection of chloroplast $\mathrm{Cu} / \mathrm{Zn}$ SOD from $\mathrm{NaCl}$ stress.

\section{KcCSD EXPRESSION AND ROS CONTROL IN CHLOROPLAST}

Phylogenetic tree and sequence analyses have verified that KcCSD is a chloroplast CSD (Figure 4). The deduced protein sequence 


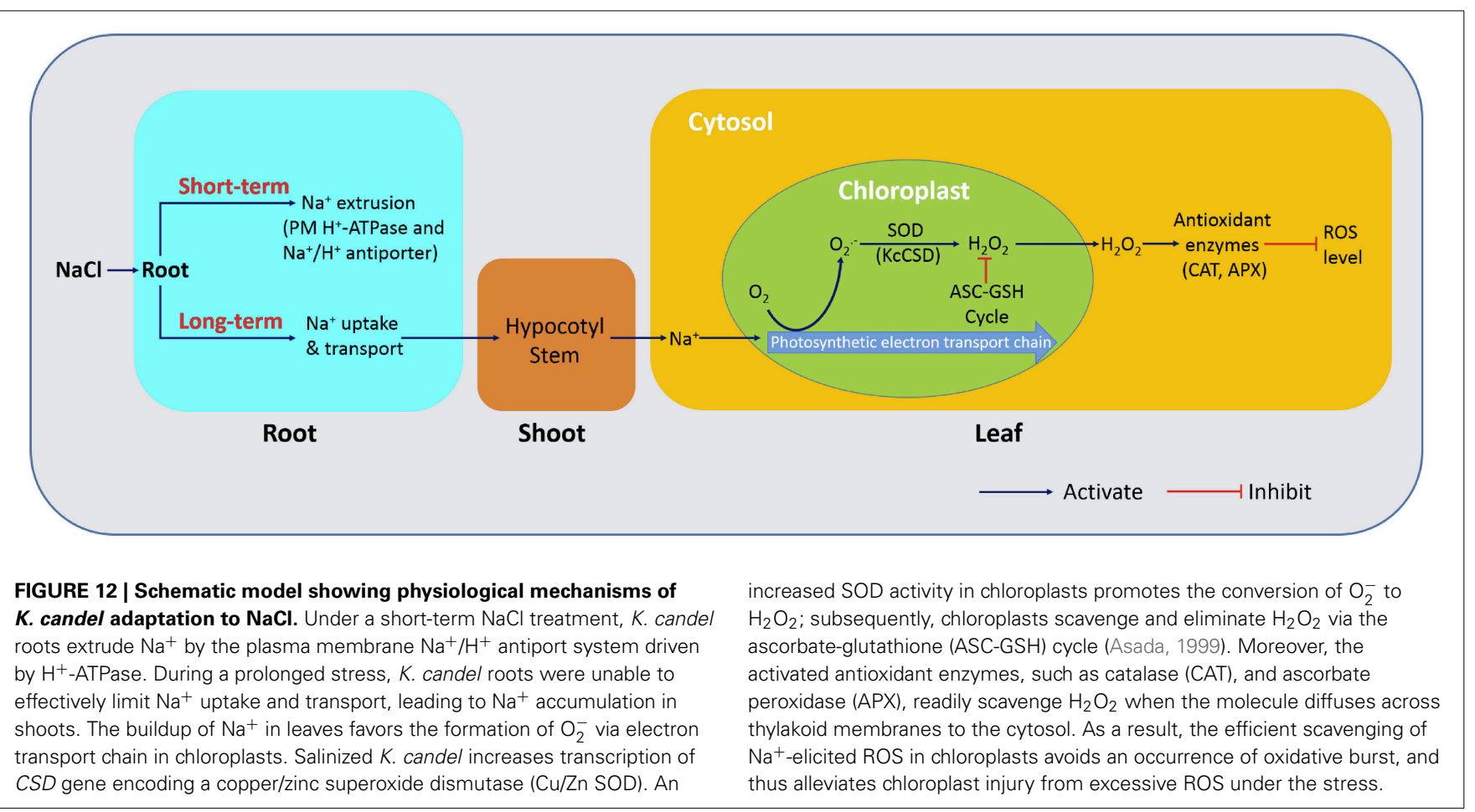

has confirmed a high similarity to chloroplast CSDs from other species, such as Bruguiera gymnorrhiza, Dimocarpus longan, Gossypium hirsutum, and Arabidopsis thaliana (Figure 4). In agreement with sequence analysis, a subcellular location assay revealed that KcCSD protein is targeted to chloroplast (Figure 5). Similarly, Arabidopsis CSD2 localized in chloroplast (Kliebenstein et al., 1998; Huang et al., 2012). ROS analysis in transgene tobacco plants indicated that KcCSD was involved in protecting chloroplasts from $\mathrm{Na}^{+}$damage. $\mathrm{NaCl}$ treatment caused a significant increase in leaf $\mathrm{H}_{2} \mathrm{O}_{2}$ (Figure 8) and WT tobacco chloroplast (Figure 9). The $\mathrm{H}_{2} \mathrm{O}_{2}$ burst in chloroplast resulted from the SODcatalyzed conversion of $\mathrm{O}_{2}^{-}$. It was formed predominantly at a high rate of electron transfer to $\mathrm{O}_{2}$ (Asada, 1999; Apel and Hirt, 2004). The $\mathrm{Na}^{+}$-induced oxidative damage occurred in WT tobacco leaves. It led to an increased MDA and declined Pn, chlorophyll content, chlorophyll a/b ratio, Fv/Fm, and ФPSII (Figures 6-8). This was a result of high $\mathrm{H}_{2} \mathrm{O}_{2}$ in chloroplast (Figure 9; Stepien and Johnson, 2009). Excessive $\mathrm{H}_{2} \mathrm{O}_{2}$ has been shown to trigger membrane lipid peroxidation, and limit membrane lipid unsaturation and membrane protein polymerization (Bowler et al., 1992; Wang et al., 2007).

Compared to WT tobacco plants, KcCSD-transgenic plants accumulated less $\mathrm{H}_{2} \mathrm{O}_{2}$ in both leaves and chloroplast under $\mathrm{NaCl}$ stress (Figures 8, 9). Unexpectedly, $\mathrm{NaCl}$-treated transgenic plants retained higher $\mathrm{O}_{2}^{-}$production than WT (Figure 8). The high $\mathrm{O}_{2}^{-}$in salinized transgenic plants was likely due to feedback activation of $\mathrm{O}_{2}^{-}$production system. A high conversion of $\mathrm{O}_{2}^{-}$to $\mathrm{H}_{2} \mathrm{O}_{2}$ in $\mathrm{KcCSD}$-transgenic plants accelerated the electron transfer to $\mathrm{O}_{2}$ via photosynthetic electron transport chain, thus activating positive feedback production of $\mathrm{O}_{2}^{-}$. A lower $\mathrm{H}_{2} \mathrm{O}_{2}$ in $\mathrm{KcCSD}$-transgenic plants mainly resulted from an increased activity of antioxidant enzymes (Figures 10, 11). Under either 24-h or 7-day $\mathrm{NaCl}$ stress, KcCSD-transgenic tobacco plants increased total activity of SOD due to an increment of SOD isoenzymes (Figures 10, 11). Moreover, in transgenic plants, $\mathrm{NaCl}$ treatment rapidly increased CAT after $8 \mathrm{~h}$ of salinity (Figure 10). Increased activities of CAT arose from an increased production of $\mathrm{O}_{2}^{-}$and $\mathrm{H}_{2} \mathrm{O}_{2}$, as ROS are secondary messengers to induce antioxidant defenses (Desikan et al., 2001; Vranová et al., 2002). It is evidenced that the antioxidant enzymes SOD, CAT, and APX play a crucial role in maintaining $\mathrm{O}_{2}^{-}$and $\mathrm{H}_{2} \mathrm{O}_{2}$ balance in the plants (Payton et al., 2001). Hence, increased activity of $\mathrm{SOD}$ in transgenic plants promoted the conversion of $\mathrm{O}_{2}^{-}$to $\mathrm{H}_{2} \mathrm{O}_{2}$ (Bowler et al., 1992; Fridovich, 1995) and CAT activation. Consequently, increased CAT would assist transgenic plants in reducing $\mathrm{NaCl}$-elicited $\mathrm{H}_{2} \mathrm{O}_{2}$ in leaf cells during an extended $\mathrm{NaCl}$ stress (Figures 8, 9). Similar findings were observed in K. candel under $\mathrm{NaCl}$ treatment. Li (2009) showed that K. candel increased activities of SOD, CAT, APX, and glutathione reductase (GR) in leaves to control ROS during $\mathrm{NaCl}$ stress.

\section{CONCLUSIONS}

This study has revealed that $K$. candel has different physiological mechanisms to adapt to $\mathrm{NaCl}$ stress (Figure 12). As shown in the schematic model, $K$. candel roots could maintain a high capacity to extrude $\mathrm{Na}^{+}$via a $\mathrm{PM} \mathrm{Na}{ }^{+} / \mathrm{H}^{+}$antiport system driven by $\mathrm{H}^{+}$-ATPase. Under a prolonged stress, $K$. candel could activate its antioxidant system when roots were unable to effectively limit $\mathrm{Na}^{+}$uptake and transport in the plant. The buildup of $\mathrm{Na}^{+}$in leaves would favor the formation of $\mathrm{O}_{2}^{-}$via electron transport chain in chloroplast. $K$. candel could also upregulate $C S D$ in leaves to detoxify $\mathrm{Na}^{+}$-elicited ROS and thus avoid an 
occurrence of oxidative burst. Ectopic expression of $K c C S D$ in tobacco revealed that KcCSD could control ROS in chloroplast during $\mathrm{NaCl}$ stress. Accordingly, salinized $K$. candel increased $\mathrm{Cu} / \mathrm{Zn} \mathrm{SOD}$ activity to promote the conversion of $\mathrm{O}_{2}^{-}$to $\mathrm{H}_{2} \mathrm{O}_{2}$; subsequently, chloroplasts scavenged and eliminated $\mathrm{H}_{2} \mathrm{O}_{2}$ via the ascorbate-glutathione cycle (Asada, 1999). Moreover, the activated antioxidant enzymes, such as CAT and APX in the cytosol could readily scavenge the $\mathrm{Na}^{+}$-elicited $\mathrm{H}_{2} \mathrm{O}_{2}$ when $\mathrm{H}_{2} \mathrm{O}_{2}$ diffused across thylakoid membranes to the cytosol. The effective scavenge of $\mathrm{Na}^{+}$-elicited $\mathrm{H}_{2} \mathrm{O}_{2}$ in chloroplast alleviated chloroplast injury from excessive ROS under the stress. As a result, photochemical efficiency inhibition was physiologically mitigated and benefitted the plant for maintaining its photosynthesis and growth under the longer term salinity. Signaling network regulating $K c C S D$ transcription under $\mathrm{NaCl}$ stress needs to be further investigated in the future.

\section{AUTHOR CONTRIBUTIONS}

Xiaoshu Jing designed and performed the experiments, analyzed the experimental data, and prepared the manuscript. Peichen Hou, Yanjun Lu, Shurong Deng, Niya Li, Yang Wang, Yansha Han, and Tao Lang partly participated in the experiments (Peichen Hou: gene cloning and expression analysis of KcCSD in Kandelia candel, Yanjun Lu: $\mathrm{Na}^{+}$fluxes recording in roots and $\mathrm{Na}^{+}$concentrations, Shurong Deng subcellular location of KcCSD). Rui Zhao designed KcCSD-GFP construct. Rui Zhao, Jian Sun, Mingquan Ding, and Xin Shen conceived research plan. Shaoliang Chen designed research work and revised the manuscript. All authors have read and approved the final version of this manuscript.

\section{ACKNOWLEDGMENTS}

This research was supported jointly by National Natural Science Foundation of China (Grant Nos. 31270654, 31160150), Research Project of Chinese Ministry of Education (Grant No. 113013A), key project for Overseas Scholars by Ministry of Human Resources and Social Security of P. R. China (Grant No. 2012001), Program of Introducing Talents of Discipline to Universities (Plan 111 Project, Grant No. B13007), and Program for Changjiang Scholars and Innovative Research Teams of the University (Grant No. IRT13047).

\section{SUPPLEMENTARY MATERIAL}

The Supplementary Material for this article can be found online at: http://www.frontiersin.org/journal/10.3389/fpls.2015. 00023/abstract

\section{REFERENCES}

Aebi, H. (1984). Catalase in vitro. Meth. Enzymol. 105, 121-126.

Apel, K., and Hirt, H. (2004). Reactive oxygen species: metabolism, oxidative stress, and signal transduction. Annu. Rev. Plant Biol. 55, 373-399. doi: 10.1146/annurev.arplant. 55.03-1903.141701

Asada, K. (1999). The water-water cycle in chloroplasts: scavenging of active oxygens and dissipation of excess photons. Annu. Rev. Plant Biol. 50, 601-639. doi: 10.1146/annurev. arplant.50.1.601

Beauchamp, C., and Fridovich, I. (1971). Superoxide dismutase: improved assays and an assay applicable to acrylamide gels. Anal. Biochem. 44, 276-287. doi: 10.1016/00032697-(71)90370-8

Bowler, C., Montagu, M. V., and Inze, D. (1992). Superoxide dismutase and stress tolerance. Ann. Rev. Plant Biol. 43, 83-116.
Chen, S., and Polle, A. (2010). Salinity tolerance of Populus. Plant Biol. 12, 317-333. doi: 10.1111/j.1438-8677.2009.00301.x

Cuin, T. A., Bose, J., Stefano, G., Jha, D., Tester, M., Mancuso, S., et al. (2011). Assessing the role of root plasma membrane and tonoplast $\mathrm{Na}^{+} / \mathrm{H}^{+}$exchangers in salinity tolerance in wheat: in planta quantification methods. Plant Cell Environ. 34, 947-961. doi: 10.1111/j.1365-3040.2011.02296.x

Desikan, R., Soheila, A. H., Hancock, J. T., and Neill, S. J. (2001). Regulation of the Arabidopsis transcriptome by oxidative stress. Plant Physiol. 127, 159-172. doi: 10.1104/pp.127.1.159

Dutilleul, C., Garmier, M., Noctor, G., Mathieu, C., Chétrit, P., Foyer, C. H., et al. (2003). Leaf mitochondria modulate whole cell redox homeostasis, set antioxidant capacity, and determine stress resistance through altered signaling and diurnal regulation. Plant Cell 15, 1212-1226. doi: 10.1105/tpc. 009464

Emanuelsson, O., Brunak, S., von Heijne, G., and Nielsen, H. (2007). Locating proteins in the cell using TargetP, SignalP and related tools. Nat. Protoc. 2, 953-971. doi: 10.1038/nprot.2007.131

Emanuelsson, O., Nielsen, H., and Heijne, G. V. (1999). ChloroP, a neural networkbased method for predicting chloroplast transit peptides and their cleavage sites. Protein Sci. 8, 978-984.

Fridovich, I. (1995). Superoxide radical and superoxide dismutases. Annu. Rev. Plant Biochem. 64, 97-112. doi: 10.1146/annurev.biochem.64.1.97

Giannopolitis, C. N., and Ries, S. K. (1977). Superoxide dismutases II. Purification and quantitative relationship with water-soluble protein in seedlings. Plant Physiol. 59, 315-318. doi: 10.1104/pp.59.2.315

Gutteridge, J., and Halliwell, B. (2010). Antioxidants: molecules, medicines, and myths. Biochem. Biophy. Res. Commun. 393, 561-564. doi: 10.1016/j.bbrc.2010.02.071

Han, Y., Wang, W., Sun, J., Ding, M., Zhao, R., Deng, S., et al. (2013). Populus euphratica XTH overexpression enhances salinity tolerance by the development of leaf succulence in transgenic tobacco plants. J. Exp. Bot. 64, 4225-4238. doi: 10.1093/jxb/ert229

Heath, R. L., and Packer, L. (1968). Photoperoxidation in isolated chloroplasts: I. Kinetics and stoichiometry of fatty acid peroxidation. Arch. Biochem. Biophy. 125, 189-198. doi: 10.1016/0003-9861(68)90654-1

Hoagland, D. R., and Arnon, D. I. (1950). The Water-Culture Method for Growing Plants Without Soil. Circular 347, 39. Berkeley, CA: California Agricultural Experiment Station.

Horsch, R. B., Fry, J. E., Hoffmann, N. L., Eichholtz, D., Rogers, S. A., and Fraley, R. T. (1985). A simple and general method for transferring genes into plants. Science 227, 1229-1231. doi: 10.1126/science.227.4691.1229

Hou, P. (2010). Microarray Analysis of Gene Expression Patterns and Putative Functions of Differentially Expressed Genes in Mangrove Kandelia Candel Under High-Salinity Stress. Ph.D. dissertation, 55-62, Beijing Forestry University, Beijing.

Huang, C. H., Kuo, W. Y., Weiss, C., and Jinn, T. L. (2012). Copper chaperonedependent and-independent activation of three copper-zinc superoxide dismutase homologs localized in different cellular compartments in Arabidopsis. Plant Physiol. 158, 737-746. doi: 10.1104/pp.111

Jakob, B., and Heber, U. (1996). Photoproduction and detoxification of hydroxyl radicals in chloroplasts and leaves and relation to photoinactivation of photosystems I and II. Plant Cell Physiol. 37, 629-635.

Kliebenstein, D. J., Monde, R. A., and Last, R. L. (1998). Superoxide dismutase in Arabidopsis: an eclectic enzyme family with disparate regulation and protein localization. Plant Physiol. 118, 637-650. doi: 10.1104/pp.118.2.637

Lang, T., Sun, H., Li, N., Lu, Y., Shen, Z., Jing, X., et al. (2014). Multiple signaling networks of extracellular ATP, hydrogen peroxide, calcium, and nitric oxide in the mediation of root ion fluxes in secretor and non-secretor mangroves under salt stress. Aquat. Bot. 119, 33-43. doi: 10.1016/j.aquabot.2014. 06.009

Li, N., Chen, S., Zhou, X., Li, C., Shao, J., Wang, R., et al. (2008). Effect of NaCl on photosynthesis, salt accumulation and ion compartmentation in two mangrove species, Kandelia candel and Bruguiera gymnorhiza. Aquat. Bot. 88, 303-310. doi: 10.1016/j.aquabot.2007.12.003

Li, N. (2009). Regulation of Ionic and Reactive Oxygen Species Homeostasis in Seedlings of Two Mangrove and the Relevance to Salinity. Ph.D. dissertation, 69-76, Beijing Forestry University, Beijing.

Lichtenthaler, H. K. (1987). Chlorophylls and carotenoids: pigments of photosynthetic biomembranes. Meth. Enzymol. 148, 350-382. 
Livak, K. J., and Schmittgen, T. D. (2001). Analysis of relative gene expression data using real-time quantitative PCR and the $2^{-\Delta \Delta \mathrm{C}_{\mathrm{T}}}$ method. Methods 25 , 402-408. doi: 10.1006/meth.2001.1262

Lu, Y., Li, N., Sun, J., Hou, P., Jing, X., Zhu, H., et al. (2013). Exogenous hydrogen peroxide, nitric oxide and calcium mediate root ion fluxes in two nonsecretor mangrove species subjected to $\mathrm{NaCl}$ stress. Tree Physiol. 33, 81-95. doi: 10.1093/treephys/tps119

Maxwell, K., and Johnson, G. N. (2000). Chlorophyll fluorescence-a practical guide. J. Exp. Bot. 51, 659-668. doi: 10.1093/jexbot/51.345.659

Murashige, T., and Skoog, F. (1962). A revised medium for rapid growth and bio assays with tobacco tissue cultures. Physiol. Plant. 15, 473-497. doi: 10.1111/j.1399-3054.1962.tb08052.x

Nakano, Y., and Asada, K. (1981). Hydrogen peroxide is scavenged by ascorbatespecific peroxidase in spinach chloroplasts. Plant Cell Physiol. 22, 867-880.

Payton, P., Webb, R., Kornyeyev, D., Allen, R., and Holaday, A. S. (2001). Protecting cotton photosynthesis during moderate chilling at high light intensity by increasing chloroplastic antioxidant enzyme activity. J. Exp. Bot. 52, 2345-2354. doi: $10.1093 /$ jexbot/52.365.2345

Polle, A., and Chen, S. (2014). On the salty side of life: molecular, physiological and anatomical adaptation and acclimation of trees to extreme habitats. Plant Cell Environ. doi: 10.1111/pce.12440. [Epub ahead of print].

Prashanth, S. R., Sadhasivam, V., and Parida, A. (2008). Over expression of cytosolic copper/zinc superoxide dismutase from a mangrove plant Avicennia marina in indica Rice var Pusa Basmati-1 confers abiotic stress tolerance. Transgenic Res. 17, 281-291. doi: 10.1007/s11248-007-9099-6

Ramírez, L., Bartoli, C. G., and Lamattina, L. (2013). Glutathione and ascorbic acid protect Arabidopsis plants against detrimental effects of iron deficiency. J. Exp. Bot. 64, 3169-3178. doi: 10.1093/jxb/ert153

Shen, Z., Ding, M., Sun, J., Deng, S., Zhao, R., Wang, M., et al. (2013). Overexpression of PeHSF mediates leaf ROS homeostasis in transgenic tobacco lines grown under salt stress conditions. Plant Cell Tiss. Org. Cult. 115, 299-308. doi: $10.1007 /$ s1 1240-013-0362-7

Stepien, P., and Johnson, G. N. (2009). Contrasting responses of photosynthesis to salt stress in the glycophyte Arabidopsis and the halophyte Thellungiella: role of the plastid terminal oxidase as an alternative electron sink. Plant Physiol. 149, 1154-1165. doi: 10.1104/pp.108

Sun, J., Chen, S., Dai, S., Wang, R., Li, N., Shen, X., et al. (2009a). NaClinduced alternations of cellular and tissue ion fluxes in roots of salt-resistant and salt-sensitive poplar species. Plant Physiol. 149, 1141-1153. doi: 10.1104/ pp.108

Sun, J., Dai, S., Wang, R., Chen, S., Li, N., Zhou, X., et al. (2009b). Calcium mediates root $\mathrm{K}^{+} / \mathrm{Na}^{+}$homeostasis in poplar species differing in salt tolerance. Tree Physiol. 29, 1175-1186. doi: 10.1093/treephys/tpp04

Sun, J., Li, L., Liu, M., Wang, M., Ding, M., Deng, S., et al. (2010a). Hydrogen peroxide and nitric oxide mediate $\mathrm{K}^{+} / \mathrm{Na}^{+}$homeostasis and antioxidant defense in NaCl-stressed callus cells of two contrasting poplars. Plant Cell Tiss. Org. Cult. 103, 205-215. doi: 10.1007/s11240-010-9768-7

Sun, J., Wang, M. J., Ding, M. Q., Deng, S. R., Liu, M. Q., Lu, C. F., et al. (2010b). $\mathrm{H}_{2} \mathrm{O}_{2}$ and cytosolic $\mathrm{Ca}^{2+}$ signals triggered by the $\mathrm{PM} \mathrm{H}^{+}$-coupled transport system mediate $\mathrm{K}^{+} / \mathrm{Na}^{+}$homeostasis in NaCl-stressed Populus euphratica cells. Plant Cell Environ. 33, 943-958. doi: 10.1111/j.1365-3040.2010.02118.x

Sun, J., Zhang, X., Deng, S., Zhang, C., Wang, M., Ding, M., et al. (2012). Extracellular ATP signaling is mediated by $\mathrm{H}_{2} \mathrm{O}_{2}$ and cytosolic $\mathrm{Ca}^{2+}$ in the salt response of Populus euphratica cells. PLoS ONE 7:e53136. doi: 10.1371/journal.pone.0053136

Thordal-Christensen, H., Zhang, Z., Wei, Y., and Collinge, D. B. (1997). Subcellular localization of $\mathrm{H}_{2} \mathrm{O}_{2}$ in plants. $\mathrm{H}_{2} \mathrm{O}_{2}$ accumulation in papillae and hypersensitive response during the barley-powdery mildew interaction. Plant J. 11, 1187-1194. doi: 10.1046/j.1365-313X.1997.11061187.x

Tseng, M. J., Liu, C. W., and Yiu, J. C. (2007). Enhanced tolerance to sulfur dioxide and salt stress of transgenic Chinese cabbage plants expressing both superoxide dismutase and catalase in chloroplasts. Plant Physiol. Biochem. 45, 822-833. doi: 10.1016/j.plaphy.2007.07.011

Volkov, V., Wang, B., Dominy, P. J., Fricke, W., and Amtmann, A. (2004). Thellungiella halophila, a salt-tolerant relative of Arabidopsis thaliana, possesses effective mechanisms to discriminate between potassium and sodium. Plant Cell Environ. 27, 1-14. doi: 10.1046/j.0016-8025.2003.01116.x

Vranová, E., Inze, D., and Van Breusegem, F. (2002). Signal transduction during oxidative stress. J. Exp. Bot. 53, 1227-1236. doi: 10.1093/jexbot/53.372.1227

Wan, C. Y., and Wilkins, T. A. (1994). A modified hot borate method significantly enhances the yield of high-quality RNA from cotton (Gossypium hirsutum L.). Anal. Biochem. 223, 7-12. doi: 10.1006/abio.1994.1538

Wang, L., Liang, W., Xing, J., Tan, F., Chen, Y., Huang, L., et al. (2013). Dynamics of chloroplast proteome in salt-stressed mangrove Kandelia candel (L.) Druce. J. Proteome Res.12, 5124-5136. doi: 10.1021/pr4006469

Wang, L., Liu, X., Liang, M., Tan, F., Liang, W., Chen, Y., et al. (2014). Proteomic analysis of salt-responsive proteins in the leaves of mangrove Kandelia candel during short-term stress. PLOS ONE 9:e83141. doi: 10.1371/journal.pone.0083141

Wang, R., Chen, S., Deng, L., Fritz, E., Hüttermann, A., and Polle, A. (2007). Leaf photosynthesis, fluorescence response to salinity and the relevance to chloroplast salt compartmentation and anti-oxidative stress in two poplars. Trees 21 , 581-591. doi: 10.1007/s00468-007-0154-y

Wang, R., Chen, S., Zhou, X., Shen, X., Deng, L., Zhu, H., et al. (2008). Ionic homeostasis and reactive oxygen species control in leaves and xylem sap of two poplars subjected to $\mathrm{NaCl}$ stress. Tree Physiol. 28, 947-957. doi: 10.1093/treephys/28.6.947

Wellburn, A. R. (1994). The spectral determination of chlorophylls a and b, as well as total carotenoids, using various solvents with spectrophotometers of different resolution. J. Plant Physiol. 144, 307-313. doi: 10.1016/S0176-1617(11)81192-2 Yoo, S. D., Cho, Y. H., and Sheen, J. (2007). Arabidopsis mesophyll protoplasts: a versatile cell system for transient gene expression analysis. Nature Protoc. 2, 1565-1572. doi: 10.1038/nprot.2007.199

Conflict of Interest Statement: The authors declare that the research was conducted in the absence of any commercial or financial relationships that could be construed as a potential conflict of interest.

Received: 22 October 2014; accepted: 16 December 2014; published online: 22 January 2015.

Citation: Jing X, Hou P, Lu Y, Deng S, Li N, Zhao R, Sun J, Wang Y, Han Y, Lang $T$, Ding $M$, Shen $X$ and Chen $S$ (2015) Overexpression of copper/zinc superoxide dismutase from mangrove Kandelia candel in tobacco enhances salinity tolerance by the reduction of reactive oxygen species in chloroplast. Front. Plant Sci. 6:23. doi: 10.3389/ fpls.2015.00023

This article was submitted to Plant Physiology, a section of the journal Frontiers in Plant Science.

Copyright (c) 2015 Jing, Hou, Lu, Deng, Li, Zhao, Sun, Wang, Han, Lang, Ding, Shen and Chen. This is an open-access article distributed under the terms of the Creative Commons Attribution License (CC BY). The use, distribution or reproduction in other forums is permitted, provided the original author(s) or licensor are credited and that the original publication in this journal is cited, in accordance with accepted academic practice. No use, distribution or reproduction is permitted which does not comply with these terms. 